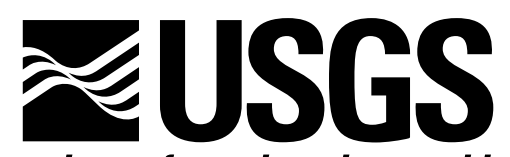

science for a changing world

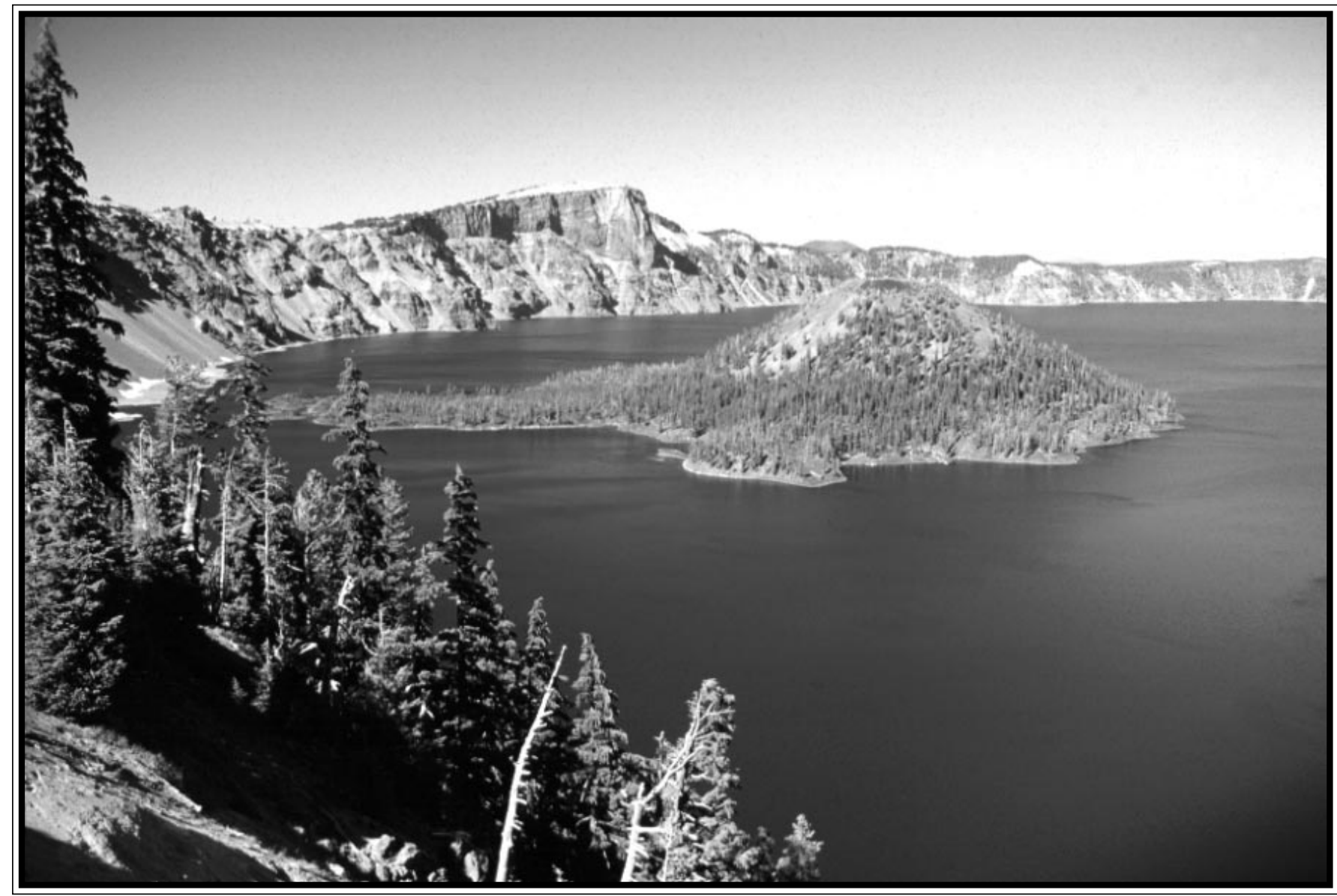

\title{
Volcano and Earthquake Hazards IN THE Crater lake Region, Oregon
}

Open-File Report 97-487

U.S. Department of the Interior

U.S. Geological Survey 
COVER: View of Crater Lakefrom the south rim of the caldera. The caldera formed 7,700 yearsago by collapse of thevolcano known as M ount M azama during thelarget explosivevolcanic eruption in thepast 400,000 years in the Cascades. The lava flows and volcanic deposits exposed in the caldera walls record the growth of M ount M azama, which attained an elevation of roughly 12,000 feet before the caldera collapsed. The prominent cliff on the north rim of the caldera is Llao Rock, a lava flow that was erupted just 200 years beforethecaldera-forming eruption. Thecinder coneand lava flows of W izard I sland were erupted within a few hundred years of formation of Crater Lake caldera. Photo by D avid E. W ieprecht. 


\section{Volcano and Earthquake Hazards in the Crater lake Region, Oregon}

by

Charles R. Bacon ${ }^{1}$, Larry G. Mastin ${ }^{2}$, Kevin M. Scott ${ }^{2}$, and Manuel Nathenson ${ }^{1}$

1 U.S. Geological Survey, 345 M iddlefield Road, M enlo Park, California

2 U.S. Geological Survey, D avid A. Johnston Cascades Volcano 0 bservatory, Vancouver, Washington

\section{Open-File Report 97-487}




\title{
U.S. DEPARTMENT OF THE INTERIOR \\ BRUCE BABBIT, Secretary \\ U.S. GEOLOGICAL SURVEY \\ MARK SCHAEFER, Acting Director
}

\author{
For sale by \\ U.S. Geological Survey, Information Services \\ Federal Center, Box 25286 \\ Denver, CO 80225
}

This report has not been reviewed for conformity with U.S. Geological Survey editorial standards or with the North American Stratigraphic Code. Any use of trade, product, or firm names in this publication is for descriptive purposes only and does not imply endorsement by the U.S. Government. 


\section{Contents}



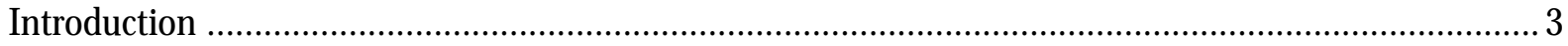

G eologic setting of $\mathrm{C}$ rater Lake ..................................................................................................... 4

Reawakening of M ount M azama................................................................................................... 7

Potential hazards from an eruption beneath Crater Lake ............................................................ 7

Factors controlling explosivity of eruptions in bodies of water .............................................. 7

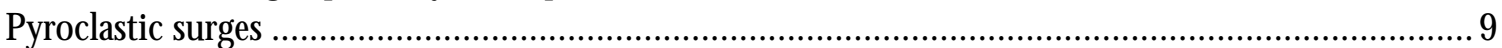

Ballistic blocks and other hazards of eruptions in the lake ....................................................... 9

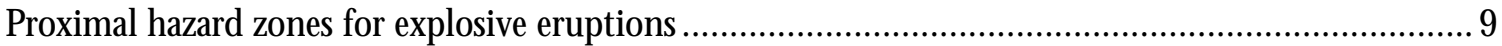

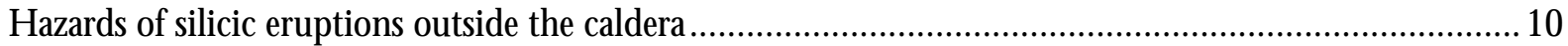

$\mathrm{H}$ azards of lahars (volcanic debris flows) and their runout flows..................................................... 10

Potential for lahars at Crater Lake .......................................................................... 11

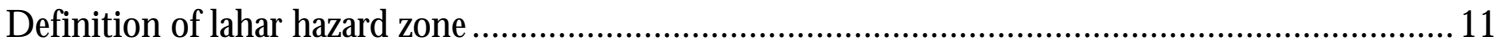

Potential size and flow velocity of lahars at Crater Lake ......................................................... 12

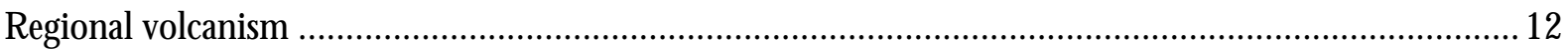

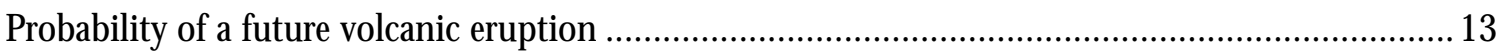

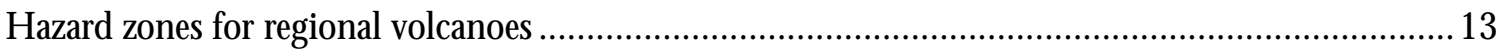

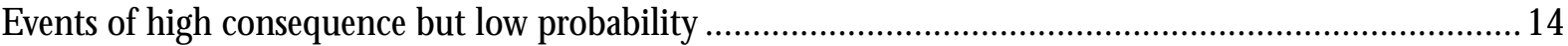

Another large volume or caldera-forming eruption? ................................................................... 14

Sudden gas release from $\mathrm{C}$ rater $\mathrm{L}$ ake ................................................................................... 16

Catastrophic flood or lahar from drainage of C rater Lake ..................................................... 16

Protecting $\mathrm{C}$ rater Lake $\mathrm{N}$ ational Park and surrounding communities from volcano hazards .................. 16

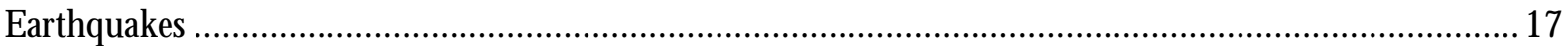

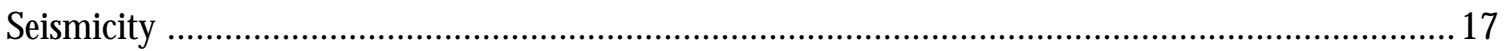

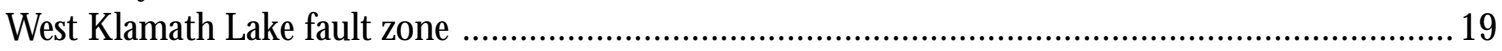

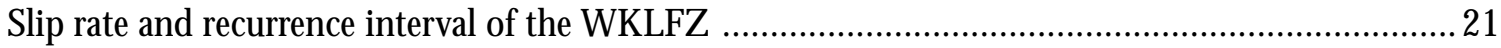

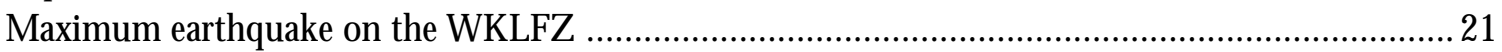

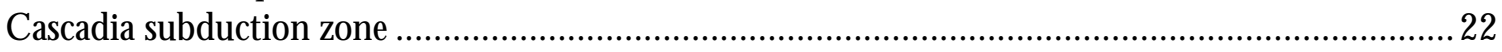

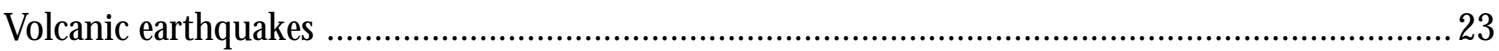

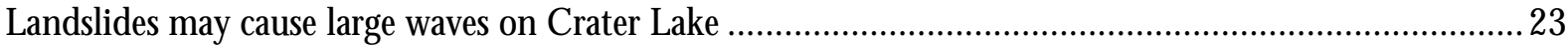

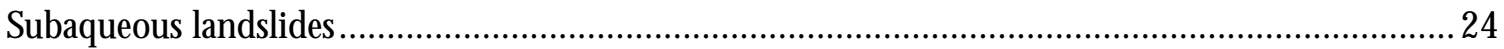

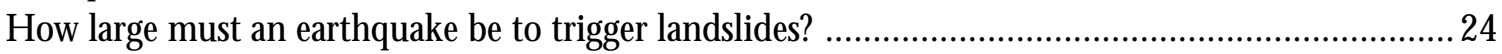



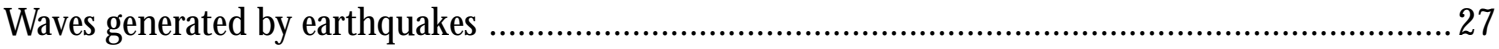

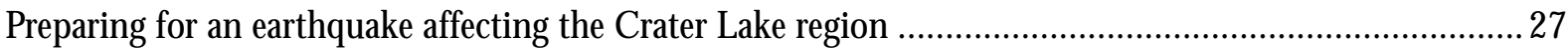

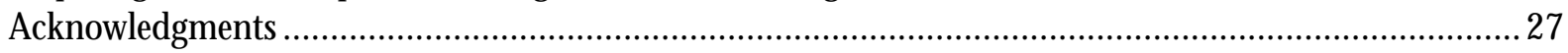

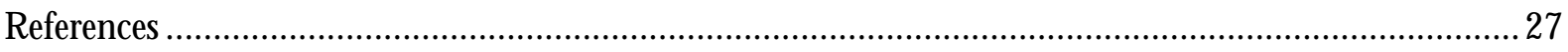

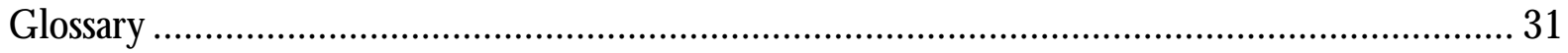




\section{Illustrations}

Page

Plate 1. M ap showing hazard zones, faults, and volcanic vents in the C rater Lake region

In pocket

Figure 1. $\quad M$ ap showing faults and volcanic vents in the $C$ rater Lake region .................................... 5

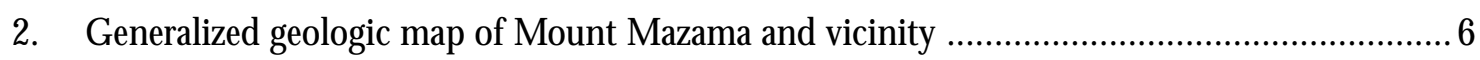

3. Geologic map of Crater Lake caldera floor ................................................................. 8

4. $\quad \mathrm{M}$ ap showing earthquake epicenters and magnitudes ................................................... 20

\section{Tables}

Table 1. Volume and flow properties of a hypothetical lahar at $C$ rater Lake based on events at M ount St. H elens, Washington, and Raupehu Volcano, N ew Zealand

2. N umbers of known basalt, basaltic andesite, and andesite volcanic vents and eruptive episodes outside $C$ rater Lake cal dera and exclusive of M ount $M$ azama between approximately latitudes $42^{\circ} 48^{\prime}$ and $43^{\circ} 05^{\prime}$

3. Seismicity in the vicinity of Crater Lakre, O regon ...................................................... 18

4. Fault offsets (down-to-the-east) and average long-term slip rates along Annie Spring and Red Cone Spring faults

5. M aximum earthquake magnitudes in the $C$ rater Lake region 23

6. Approximate minimum areas, thicknesses, and volumes of probable landslides at

Crater Lake 



\title{
VOLCANO AND EARTHQUAKE HAZARDS IN THE CRATER LAKE REGION, OREGON
}

\author{
By \\ Charles R. Bacon, Larry G. Mastin, Kevin M. Scott, and Manuel Nathenson
}

\section{Summary ${ }^{*}$}

Crater Lake lies in a basin, or caldera, formed by collapse of the Cascade volcano known as M ount $M$ azama during a violent, climactic eruption about 7,700 years ago. This event dramatically changed the character of the volcano so that many potential types of future events have no precedent there. This potentially active volcanic center is contained within Crater Lake $\mathrm{N}$ ational Park, visited by 500,000 people per year, and is adjacent to the main transportation corridor east of the $C$ ascade $R$ ange. Because a lake is now present within the most likely site of future volcanic activity, many of the hazards at C rater Lake are different from those at most other Cascade volcanoes. Also significant aremany faults near $\mathrm{C}$ rater Lake that clearly have been active in the recent past. These faults, and historic seismicity, indicate that damaging earthquakes can occur there in the future. This report describes the various types of volcano and earthquake hazards in the C rater Lake area, estimates of the likelihood of future events, recommendations for mitigation, and a map of hazard zones. The main conclusions are summarized below.
Volcanic eruptions within Crater lake CALDERA-The only volcanic eruptions in the Crater Lake area since the climactic eruption and formation of the cal dera have taken place within the caldera itself. The most recent of these was about 5,000 years ago. Future eruptions may occur within the lake where interaction of magma (molten rock) and water may produce explosionsthat can eject ba llistics (large rock fragments) and volcanic ash (rock and volcanic glass fragments smaller than 2 millimeters in diameter) outside of the caldera. Some of the ejected material would rise into the atmosphere along with expanding gas and result in blanketing of the area downwind by falling tephra (fragments of rock, frothy bits of magma, and finer-grained ash). Such explosions also can generate pyroclastic surges, ground-hugging flows of gas, steam, volcanic rock fragments, and ash moving at speeds that may exceed 100 meters per second (200 miles per hour) and which have the potential to devastate not only the area within the caldera (plate 1, Proximal $\mathrm{H}$ azard Zone A) but al so the valleys and upper slopes of M ount M azama (plate 1 , Proximal $H$ azard $Z$ Zone $B$ ). Eruptions from vents in

\footnotetext{
* Technical terms which appear in bold italics in this report are defined in the glossary. A more comprehensive glossary, descriptions of types of volcanic activity in the Cascades, and more information on volcanoes can be found at the USGS Cascades Volcano $O$ bservatory World W ide W eb site. URL: http://vulcan.wr.usgs.gov The book by D ecker and D ecker (1989) gives an illustrated, non -technical overview of volcanoes. The book by Francis (1993) is more technical and includes many case histories.
} 
shallow water may be highly explosive while those in the deep lakewould beexpected to bemuch less violent. An eruption from a vent in the caldera wall itself also might be explosive because of the abundant groundwater within the mountain. Waves on Crater Lake several meters high could be associated with explosive eruptions within the caldera. Because postcaldera volcanoes are concentrated there, the west half of the caldera is considered the most likely site of future activity. The 30-year probability of renewed volcanic activity within or very near to the caldera is greater than one chance in 330 , or $3 \times 10^{-3}$. The area within the proximal hazard zones is entirely within C rater Lake $\mathrm{N}$ ational Park where access can be controlled and the potential for loss of life can be minimized by closure of appropriate areas at the onset of seismicity or other phenomena deemed precursory to volcanic activity. The possibility of explosive eruptions that may produce ballistic rock fragments or pyroclastic surges mandates that access to the caldera and the proximal hazard zones be controlled.

LAHARS - Lahars are rapidly-moving debris flows that originate at volcanoes and consist of rock fragments carried downslope in a matrix of clay or pulverized rock and water. Lahars can travel great distances from their sources. M ost Cascade volcanoes (for example, M ount Rainier) have produced lahars in the past and are likely to continue to do so. Crater Lake differs from them in that no ice-clad summit or fragile mountaintop remains as a source of water and debris at high elevation. H owever, should an eruption occur within Crater Lake near the shoreline with sufficient violence to eject lake water from the caldera, abundant loose debris (left by the climactic eruption) on the upper slopes of M ount M azama and in the valleys might be mobilized to form lahars. Alternatively, an eruption outside of the caldera that resulted in rapid melting of a thick snowpack similarly might produce lahars. Such laharswould belocalized in low-lying areas and would tend to be confined to narrow canyons (plate 1, Lahar $\mathrm{H}$ azard Zone). Because of this, and the lack of development within much of the lahar hazard zone, the degree to which communities outsidethepark need to prepare for inundation by lahars is limited to recognition that such a hazard exists in the drainages around M ount M azama.
ERUPTIONS OUTSIDE OF THE CALDERA- The $O$ regon $C$ ascades includemany small volcanoes around and between the large volcanoes such as Mount $M$ azama. These small volcanoes include cinder cones, fissure vents, lava domes, and shield volcanoes, each of which formed in a brief period of time. They are the result of regional volcanism. H azards include slow-moving lava flows and viscous domes, and associated tephra falls, surges, and pyroclastic flows. If surges or pyrocla stic flows occur, such as might be expected for an eruption in a low-lying (wet) location, the area affected by them likely would be only a few square kilometers. Tephra falls may be significant near the vent and for a few kilometers downwind. Lava flows will advance slowly enough that they will pose a threat only to property and structures. Because exact locations of future eruptions cannot be predicted, we have estimated annual and 30-year probabilities of an eruption occurring in a particular area. Thetwo hazard zones for regional volcanism shown on plate $1(\mathrm{RH}$ and $R L$ ) indicate higher probabilities approximately west of the main axis of the Cascades and lower probabilities to the east. The probability of eruption of a new volcanic vent near Crater Lake is sufficiently small (30-year probability $=3 \times 10^{-3}$ to $3 \times 10^{-4}$ ) that potential hazards from regional volcanism need only be considered significant when even this small degree of risk to a specific facility is unacceptable.

VOLCANO-RELATED EVENTS OF HIGH CONSEQUENCE BUT LOW PROBABILITY- (1) A large pyroclastic eruption, such as the one during which the caldera formed or the (smaller) 1991 eruption of M ount Pinatubo, Philippines, is not considered likely for many thousands of years in the future because the magma reservoir which fed the climactic eruption of $M$ ount $M$ azama has not had sufficient time to regenerate a large volume of gas-rich magma. (2) Sudden gas release from Crater Lake would seem to be a possibility by comparison with the lethal release of cold carbon dioxide gas from Lake N yos, Cameroon, in 1986. H owever, natural mixing of deep water with nearsurface water in Crater Lake prevents volcanic carbon dioxide from accumulating near the lake bottom. As long as the natural mixing process continues, sudden gas release is not considered to be a significant hazard at $C$ rater Lake. (3) C atastrophic draining of Crater Lake 
is an extremely unlikely event but one which would have disastrous consequences for downstream lowlands in the affected tributary drainages. There appears to be no mechanism, short of another caldera-forming eruption, that could either eject most of the water in the lake or cause the caldera wall to fail.

EARTHQUAKES-The West Klamath Lake fault zone (WKLFZ), composed of several individual faults with lengths of up to $15 \mathrm{~km}$ and an aggregate length of 50 to $70 \mathrm{~km}$, has been mapped through C rater Lake $\mathrm{N}$ ational Park west of the caldera (plate 1 ). 0 ne of its constituent faults, the Annie Spring fault, passes less than $1 \mathrm{~km}$ west of Rim Village. All of the faults of the W KLFZ trend approximately north-south and have mainly dip-slip displacement such that the east side is dropped down relative to the west side. By determining the ages of lava flows that have been offset by the faults, the long-term rate of vertical displacement is known to be about 0.3 millimeters per year. The lengths of the faults and the measured displacements suggest that the W KLFZ is capable of tectonic earthquakes as large as magnitude (M) $7^{1 / 4}$. The recurrence interval of large earthquakes is unknown but probably is between 3,000 and 10,000 years. Although few earthquakes have been recorded in the C rater Lake area, theknown eventsare consistent with theW KLFZ being active. M oreover, the September 1993, Klamath Falls earthquakes (the two largest events were $M \approx 6.0$ ) occurred farther south along the same general zone. $M$ any other potentially active faults are present east of the C ascades, notably al ong the east side of K lamath valley (East Klamath Lake fault zone). Local volcanic earthquakes would produce ground motion at C rater Lake but thelikely maximum magnitude of such events is about 5, significant but far smaller than for tectonic earthquakes. An additional source of earthquakes is the $C$ ascadia subduction zone, thefault zonethat forms the boundary between the tectonic plates that contain the N orth American continent and the Pacific $O$ cean floor. Although distant, the potential for this zone to generate $M=8-9$ earthquakes means that shaking of up to several minutes duration could occur at Crater Lake.

Earthquakehazards in the greater Crater Lakearea are similar to those in other earthquake-prone areas, namely damage to structures, utilities, communication lines, and transportation systems. Rockfalls and landslides are significant hazards below steep canyon or caldera walls. Should a large mass of rock fall or slide rapidly from the caldera wall into Crater Lake, one or more large waves could be generated. Waves could be many meters high and travel across the lake in as little as two minutes, such as from Chaski Bay to the boat landing at Cleetwood C ove. Volcanic, local tectonic, or distant Cascadia subduction zone earthquakes all could produce shaking adequate to trigger sliding of the fractured and poorly consolidated rock of the caldera walls and talus slopes. Earthquake shaking alone, without rapid entry of slidematerial into $C$ rater Lake, would not be expected to cause dangerous waves.

\section{INTRODUCTION}

Crater Lake $\mathrm{N}$ ational Park is visited by about 500,000 people each year, with heaviest use during the summer months. Crater Lake partially fills a type of volcanic depression called a caldera that formed by collapse of a 12,000 foot volcano known as M ount $M$ azama during an enormous pyroclastic eruption approximately 7,700 years ago. Although this C ascade volcano does not directly threaten large population centers, it does pose a hazard to facilities and people at Crater Lake $\mathrm{N}$ ational Park and to the major transportation corridor east of the Cascades. The ultimate causes of volcanic activity at all Cascade volcanic centers are linked by common processes. $\mathrm{H}$ owever, $\mathrm{C}$ rater Lake is unique in many regards, and potential effects of futureactivity cannot beanticipated by analogy with past eruptions thereor at other $C$ ascade volcanoes. Profound changes occurred at Crater Lake about 7,700 years ago that affect the type of eruptions that can occur and the consequences of such events for the surrounding area. This report attempts to forecast what may happen in such future, but largely unprecedented events.

The caldera-forming or climactic eruption of $M$ ount $M$ azama changed the landscape all around the volcano. Pyroclastic flows devastated the surrounding area, including all of the river valleys that drained M ount M azama to as far as $70 \mathrm{~km}$ away, and a blanket of pumice and ash fell to the northeast of 
the volcano at least as far as southern $C$ anada. Erosion removed much of this material, feeding rivers that carried it far from its source, ultimately into the Pacific $O$ cean. Prior to the climactic event, $M$ ount $M$ azama had a 400,000 year history of activity more likethat of other $C$ ascade volcanic centers such as M ount Shasta. Since the climactic eruption, there have been several less violent, smaller postcaldera eruptions within the caldera itself. In addition, many short-lived volcanoes have erupted at various times in the $C$ rater Lake region, most recently about 10,000 years ago. We recognize that volcanic hazards at $C$ rater Lake fall into two main categories: eruptions within the caldera, reflecting reawakening of the $M$ azama system, in which Crater Lake itself plays an important role in determining eruptiveviolence, and eruptionsfrom new vents in the surrounding region.

Volcanic eruptions are not the only geologic hazards at $C$ rater $L$ ake. The $C$ rater Lake region is cut by many faults, some of which arecapable of producing damaging earthquakes (e.g., K lamath Falls, September 1993). N ot only do earthquakes pose direct hazards to people and structures but they also can cause rockfalls and landslides which, if they entered the lake rapidly, could produce life-threatening waves. Consequently, this report containsinformation about faults, seismicity, and possible effects of earthquake shaking in addition to an evaluation of volcano hazards.

\section{GEOLOGIC SETTING OF CRATER LAKE}

M ount M azama and Crater Lake caldera lie at the intersection of the Cascade chain of volcanoes with the K lamath graben, a north-northwest trending basin bounded by faults whose displacement is mainly vertical (fig. 1). At this latitude, the western margin of the Basin and Range province, characterized by north-south to northwest-southeast trending faults, impinges upon the $C$ ascades. Focusing of volcanism at $\mathrm{C}$ rater Lake and the development of the shallow magma chamber which fed the climactic eruption are linked to this regional tectonic situation.
$\mathrm{N}$ orth and south of $\mathrm{Crater}$ Lake aremany shield volcanoes of modest size and many more cinder cones with associated lava flow fields. Both represent short-lived activity at isolated vents. These monogenetic volca noes are manifestations of regional volcanism throughout the $O$ regon $C$ ascades.

M ount M azama is the name applied to the volcano in which Crater Lake caldera formed (fig. 2). Before the caldera-forming eruption, the summit of M ount M azama stood at $\sim 3,700 \mathrm{~m}$ ( 12,000 feet) elevation. M ount $M$ azama was constructed during the last approximately 400,000 years by episodic growth of many overlapping shield and composite volcanoes, each of which probably was active for a comparatively brief period (Bacon, 1983). The erupted magma was mainly andesite. Asthe volcanic complex evolved, so did its eruptive style, such that the last $\sim 70,000$ years saw morehighly explosiveeruptions of silicic magma (dacite and rhyodacite). In the last $\sim 30,000$ years, theonly record of activity, prior to thecaldera-forming climactic eruption of $\sim 7,700$ years ago, was limited to a small number of preclima ctic pyroclastic eruptions and ensuing lava flows of rhyodacite. Subsequent to the climactic eruption, all volcanic activity has occurred within the caldera itself. W izard I sland is a cinder cone and lava flows of postcaldera andesite, erupted soon after the caldera formed. Several more postcaldera volcanoes are hidden by the lake (fig. 3).

The remainder of this report discusses volcano hazards ${ }^{1}$, followed by those related to earthquakes ${ }^{2}$. The most probable types of volcanic activity and their respective hazard zones are described first, namely, reawakening of $M$ ount $M$ azama, eruptions in Crater Lake, lahars, and eruptions outside of the caldera. These are followed by the low probability, high consequence events of another caldera-forming eruption and sudden gas release from the lake. In subsequent sections, potential magnitudes of earthquakes are estimated and hazards of earthquakeinduced landslides are evaluated. Suggestions for mitigation are given at the ends of both the volcano and earthquake hazard sections.

1 The recent book by Scarpa and Tilling (1996) contains many papers on volcano monitoring, eruptive phenomena, hazards and risk assessment, and emergency management.

2 See Wong and Bott (1995) for a useful overview of earthquakes in O regon. 


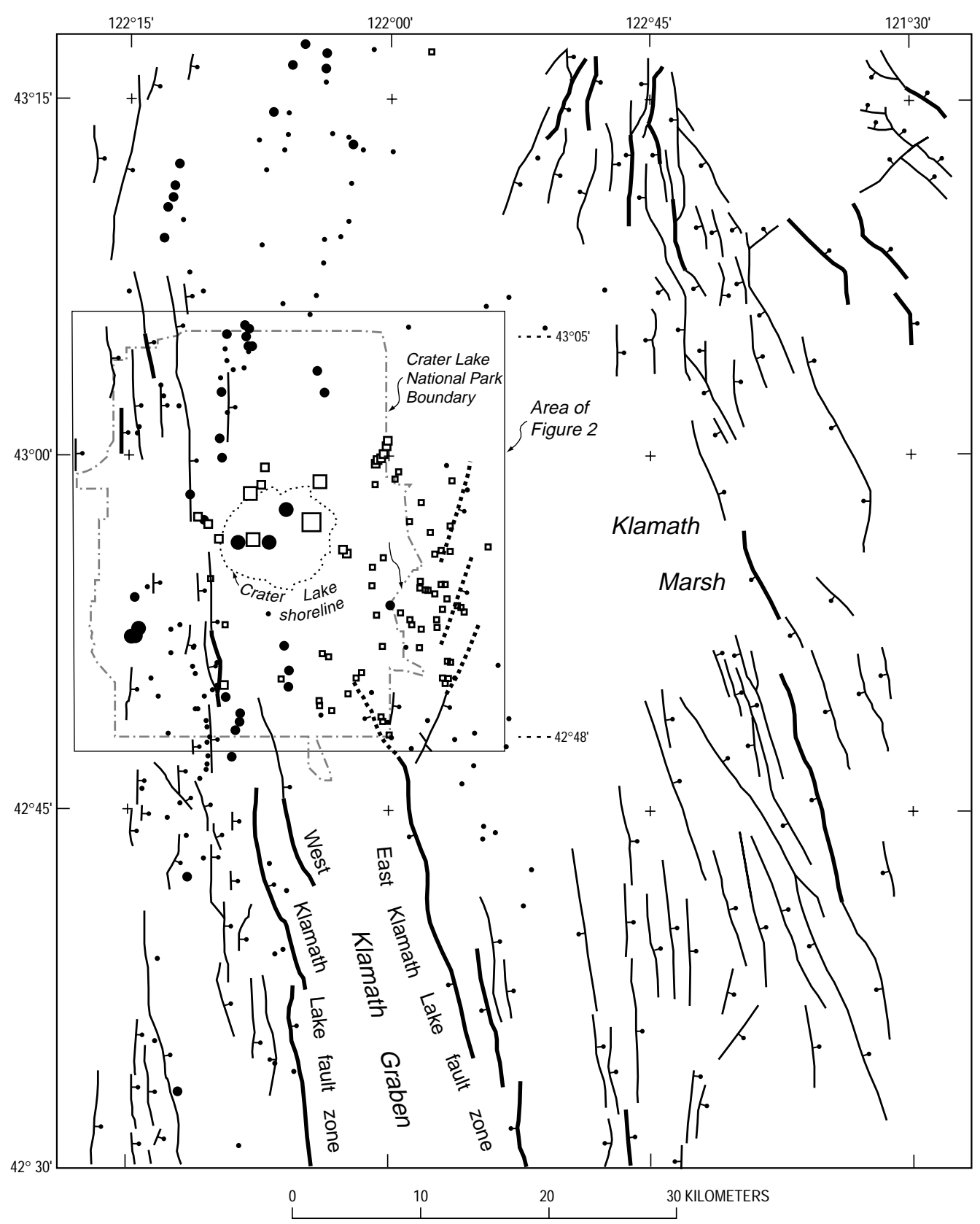

EXPLANATION

Volcanic vents

$\begin{array}{lll}\square \quad 7.7 \text { ka climactic } & -<10 \text { ka mafic } \\ \square \quad<10 \text { ka silicic } & \bullet 10-100 \text { ka mafic } \\ \square \quad 10-100 \text { ka silicic } & \bullet & 0.1-1 \text { Ma mafic } \\ \square \quad 0.1-1 \text { Ma silicic } & & \end{array}$

Faults

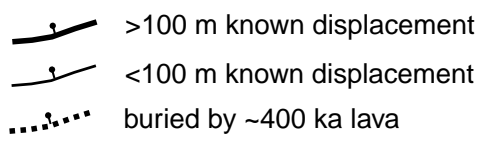

FiguRE 1.- M ap showing faults and volcanic vents in the $C$ rater Lake region (Plate 1 covers a slightly larger area at $1: 100,000$ scale and includes hazard zones). D ata sources: H awkins and others (1989), M acLeod and Sherrod (1992), Sherrod (1991), Sherrod and Pickthorn (1992), Smith (1988), Smith and others (1982), C. R. Bacon (unpublished mapping, 1996), and M . A. Lanphere (unpublished K-Ar ages, 1996). 
Bacon, Mastin, Scott, and Nathenson
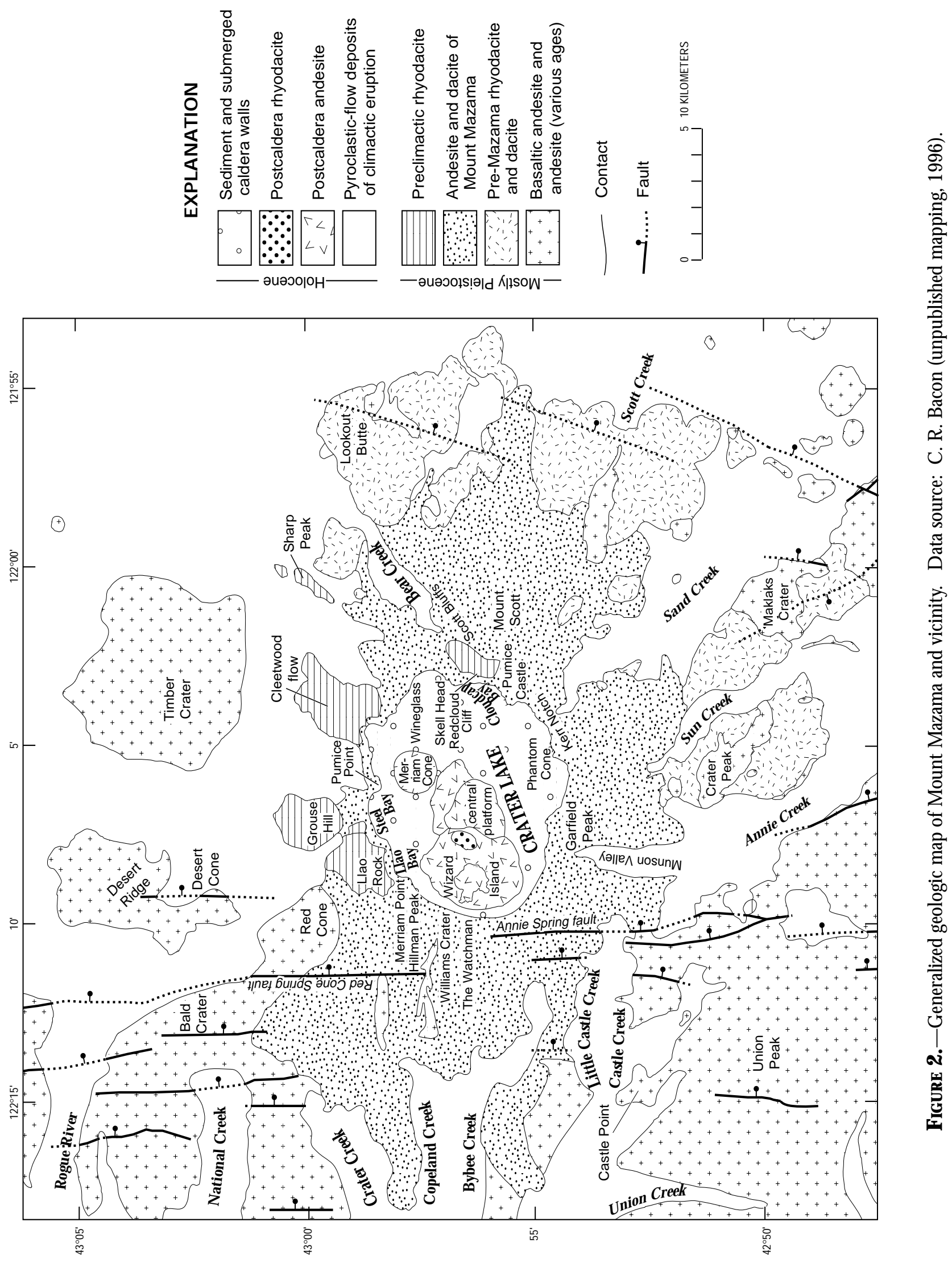


\section{REAWAKENING OF MOUNT MAZAMA}

The long history of volcanism at M ount M azama strongly suggests that this vol canic center will beactive in the future. The record of past eruptions shows us how the volcano behaved before the system was perturbed by the climactic eruption and caldera formation. Eruptions of M ount M azama were more frequent than those of the monogenetic volcanoes around it. As the volcano grew, the focus of activity migrated in a west-northwest direction. Someeruptive episodes were much longer and produced a far greater volume of materials than others. Likewise, the lengths of repose periods must have varied considerably. M ost of the vents that produced the lavas of M ount M azama were within the area circumscribed by the present caldera. Vents for silicic magma that tapped into the $M$ azama system are mainly within $2 \mathrm{~km}$ and all within $11 \mathrm{~km}$ of the caldera rim.

W izard I sland and theother postcal dera volcanoes (fig. 3) are evidence of renewed activity of Mount $M$ azama following its climactic eruption. Postcaldera volcanism is common at calderas worldwide ( $\mathrm{N}$ ewhall and D zurisin, 1988). As all postcaldera volcanism was restricted to the caldera, and given the eruptive history of $M$ azama with its west-northwest vent migration, we anticipate that the most likely site of the next eruption probably will be within the western part of the caldera. We have no basis for estimating a finite probability of volcanic eruptions from a reawakened M azama system because of the dramatic changes that occurred as a result of the climactic eruption. Judging from the overall eruptive history of Mount M azama and the surrounding region, renewed volcanic activity within or very near to the caldera is at least as likely as the birth of a new volcano within Regional $\mathrm{H}$ azard Zone RH (around one chancein 10,000, or 10-4, or a 30-year probability of about one chance in 330 , or $3 \times 10^{-3}$; see Probability of a future volcanic eruption). We do not havesufficient information to evaluate the significance of the 5,000 year repose period since the last eruption in terms of its possibleeffect on the probability of future volcanic eruptions. Futureeruptions within thecaldera may be explosive (see Potential hazards from an eruption beneath ( rater Lake). Eruptions outside of the caldera and fed by the M azama system might produce andesite lava and tephra with hazards akin to those of regional volcanism (see Regional volcanism). Alternatively, the M azama system might generateslowly emplaced, viscous daciteto rhyodacitedomes that may be preceded or accompanied by explosiveeruptions (see $\mathrm{H}$ azards of silicic eruptions outside the caldera).

\section{POTENTIAL HAZARDS FROM AN ERUPTION BENEATH CRATER LAKE}

Although future eruptions could occur anywhere within C rater Lake caldera, all known postcaldera eruptionstook placein thewest half of thelake (fig. 3). Those eruptions produced andesite lava flows and tephra (W izard Island, M erriam Cone, and the central platform), as well as a rhyodacite dome and minor ash fall. These events occurred between $\sim 7,700$ and $\sim 5,000$ years ago, most before the lake had risen to its present level. Any ash deposits above the shore of C rater Lake, which would have provided a record of associated explosive activity, evidently have been lost to erosion. Evaluation of hazards from eruptions beneath the lake must be based on historic eruptions elsewhere and knowledge of the general characteristics of volcanic eruptions in water.

\section{FACTORS CONTROLLING EXPLOSIVITY OF ERUPTIONS IN BODIES OF WATER}

The presence of $\mathrm{Crater}$ Lake creates potential hazards from futureeruptions that had not existed prior to formation of the caldera $\sim 7,700$ years ago. O ne such hazard is the violent mixing of lake water with erupting magma to produce a hydromagmatic eruption. Some famous eruptions became explosive when magma apparently mixed with shallow sea or lake water (e.g., Surtsey volcano, Iceland, 1964, described by M oore, 1985; Taal volcano, Philippines, 1965, described by Moore and others, 1966). In other eruptions, however, explosions caused by magma/water mixing have been less violent. Factors that determine how violently water and magma interact include the type of magma, its rate of extrusion, the degreeto which the magma is fragmented by expanding internal gas bubbles, and water depth (M astin, 1995).

Explosive water/magma mixing is most common in shallow water (a few meters to tens of meters deep) 


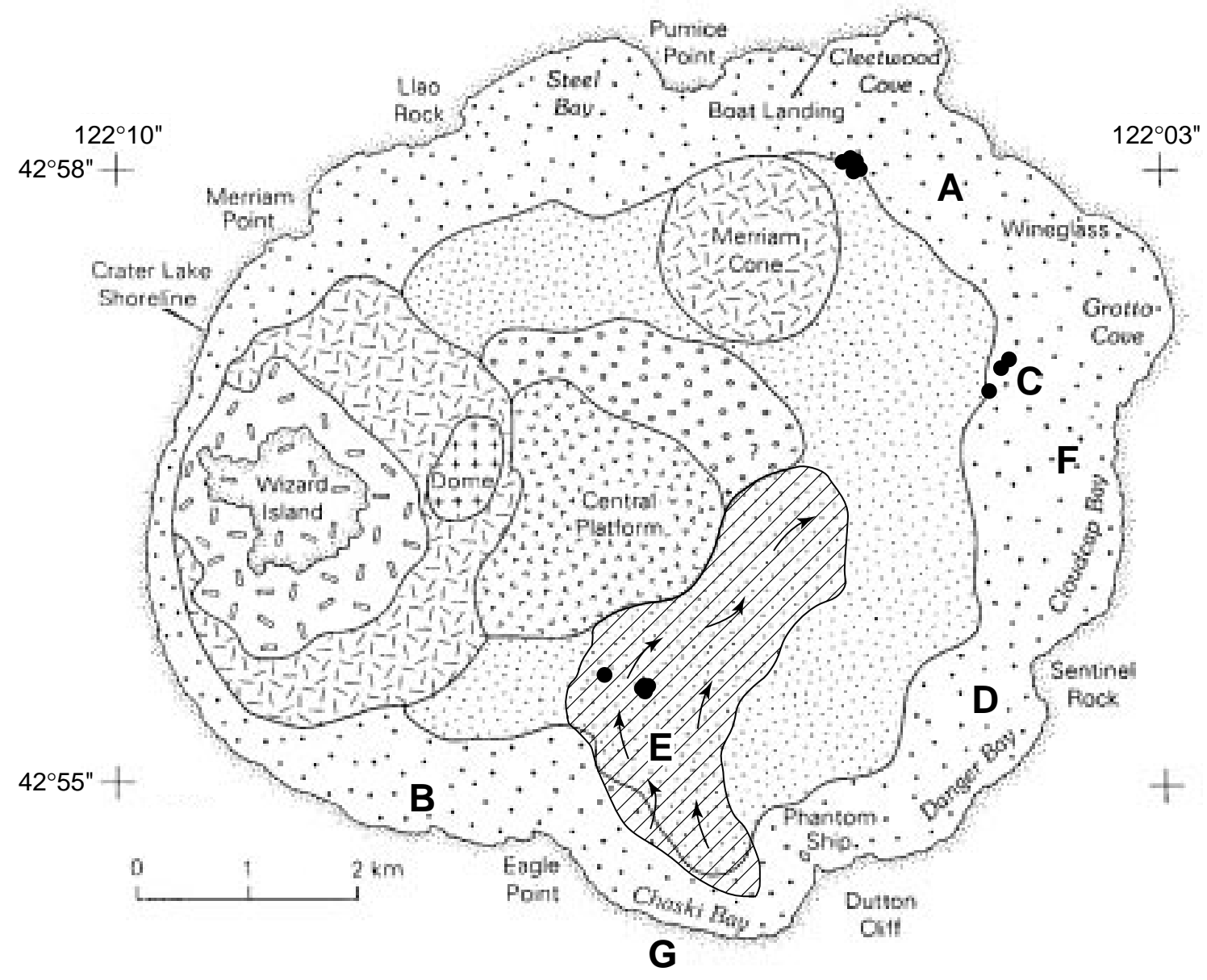

\section{EXPLANATION}

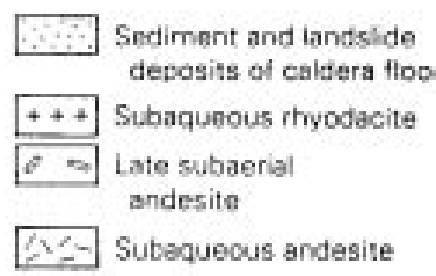

- Thermal feature

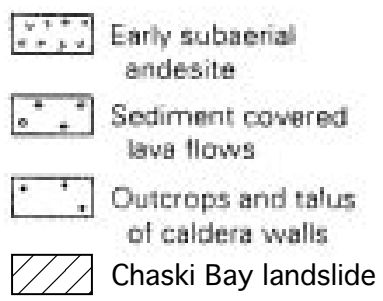

FiguRE 3. - G eologic map of Crater Lake caldera floor. M odified after $\mathrm{N}$ elson and others (1994). Geology inferred from bathymetry (Byrne, 1962), traverses and sampling by manned submersible, video from remotely operated vehicle, and dredged samples. Letters refer to specific bathymetric features listed in table 6. 
when magma extrudes rapidly and breaks apart into coarse particles beforeit is quenched. After contacting water, the magma can thermally fracture into micrometer-sized particles that transfer heat at explosive rates to generate steam (Wohletz, 1986). Eruptions into deep water, where the high pressure inhibits the expansion of steam, tend to be much less violent than thosethrough shallow water. Except near the shoreline, the floor of Crater Lake is at depths that would inhibit explosions.

Slow rates of lava extrusion ( $\left.\sim \mathrm{m}^{3} / \mathrm{s}\right)$, typical of lava flows or silicic domes, also inhibit violent mixing with water. For example, at Kilauea Volcano, $\mathrm{H}$ awaii, ba salt has flowed slowly into the ocean for more than a decade with relatively little explosive activity. Extrusion of silicic domes into lakes or in shallow marineenvironments has been known to have produced minor explosions. A lava domeextruded onto the floor of $C$ rater Lake could grow to sufficient height that eruptions could become explosive. Because the possibility of magma/water interaction is the dominant factor in determining explosivity for an eruption within the caldera, we consider all magma compositions to be capable of producing explosive activity from an eruption of modest volume.

\section{Pyroclastic Surges}

The most serious hazard posed by a hydromagmatic eruption is a pyroclastic surge. Surges are mixtures of air, volcanic gas, steam, and magma or rock fragments that move along the ground surface at high velocities (Waters and Fisher, 1971). Surges differ from pyroclastic flows in that they contain less solid debris, and are therefore less dense and more capable of flowing over topographic barriers. Surges may transport debris away from vents at velocities up to hundreds of meters per second (many hundreds of miles per hour). W ith temperatures that range from theboiling point of water to the temperature of magma, they can destroy or incineratemost structures and living things in their path.

The distance that a surge travels from its source is greatly dependent on the type of eruption. D iscrete explosions at well-observed volcanoes typically send surges only a kilometer or so from the vent, though some larger explosions can produce surges that travel several kilometers. The most mobile surges are generated by the most violent hydromagmatic eruptions that combinean influx of water and high rate of magma discharge over sustained periods of time. Such eruptions generate columns of ash and debris extending several kilometers or more into the atmosphere. If all or part of the gas/magma mixture in those columns is heavier than air, it falls back to earth, in some cases from plumes that have drifted kilometersfrom the vent. Gravity-driven descent of particle-laden clouds can accelerate them to high velocities. Surges from such eruptions have extended morethan 30 kilometers from their source vents.

\section{Ballistic Blocks and Other Hazards of ERUPTIONS IN THE LAKE}

A somewhat less serious hazard is the ejection of large ba llistic blocks, tens of centimeters or more in diameter, to distances up to a few kilometers. Blocks have been ejected from hydromagmatic craters at velocities ranging from less than $100 \mathrm{~m} / \mathrm{s}$ to nearly $250 \mathrm{~m} / \mathrm{s}$ (Self and others, 1980; Lorenz, 1970). At Crater Lake, blocks ejected at these velocities could travel 1 to $4 \mathrm{~km}$, and could easily overtop the caldera rim if the eruption vent were near the lake shore.

0 ther hazards include the development of water waves (seiches) during large explosions. Seiches at least a few meters in height accompanied the 1965 eruption of Taal volcano in the Philippines. Also, during an explosive eruption, surges might melt snow, or lake water might be ejected in sufficient volume, to mobilize surface debris and create lahars (volcanic debris flows) on the flanks of M ount M azama (lahars are discussed below).

\section{Proximal hazard Zones for Explosive ERUPTIONS}

The type of volcanic eruption considered most likely at Crater Lake would take place from a vent within the caldera, probably beneath the surface of the lake. We have defined Proximal $\mathrm{H}$ azard Zone PA as the caldera itself, bounded by the caldera rim (plate 1). Proximal $\mathrm{H}$ azard Zone PB is the maximum area we 
judge likely to be affected by pyroclastic surges and ballistic ejecta, assuming an eruption that breaks the surface of the lake.

Theouter boundary of Proximal $\mathrm{H}$ azard Zone PB was drawn by assuming a maximum height of ejection of surge-forming material of $500 \mathrm{~m}$ above the lake surface and a ratio of height of drop to runout distance of $1: 10$, or $H / L=0.1$, for vents within the lake and close to the shoreline (such a low ratio maximizes predicted runout). Surges would be funneled through low areas on the caldera rim and channeled into valleys. Although surges would not be expected on the higher ground, wehaveincluded the entirearea within $1.5 \mathrm{~km}$ of the rim within zone PB because of a possible hazard from exceptionally energetic ballistic blocks. For the same conditions of height of origin, surges from vents near the center of the lake would not surmount the caldera walls and ballistics would fall within the caldera. Crater Lake Lodge, Rim Village, and structures in the park headquarters area are at highest risk from an eruption in the southwest quadrant of the lake. An eruption elsewhere in the caldera might not affect this area with pyroclastic surges but might result in tephra fall there if wind conditions were appropriate.

\section{HAZARDS OF SILICIC ERUPTIONS OUTSIDE THE CALDERA}

Silicic magma generated in a reawakened $M$ azama system might erupt outside of the cal dera but within a few kilometers of the caldera rim. It is impossible to forecast this type of event or to determine where such an eruption would be most likely because of the drastic reorganization of the magmatic plumbing system that took place when the caldera formed. We believe the probability of such an eruption is less than for an eruption within the caldera. N evertheless, it is worthwhile to describe the types of phenomena that could be expected.

Silicic eruptions typically begin with hydromagmatic explosions as the slowly rising magma heats groundwater in the shallow subsurface. Such explosions will be most likely in poorly-drained areas. Commonly, explosive magmatic eruptions follow the vent-clearing, hydromagmatic phase. Both phases can produce pyroclastic surges, flows, and falls. Factors controlling the runout distances of surges and pyroclastic flows are described above (see Proximal hazard zones for explosive eruptions). H eavy rainfall on fresh pyroclastic deposits may feed lahars (see $H$ azards of lahars (volcanic debris flows) and their runout flows). Viscousmagma that has lost its original gas may eventually extrude from the vent to form a lava dome or slowly-moving flow. Relatively small pyroclastic surges or flows may form as hot lava blocks fall from the unstable dome or flow front. The smallest domesare only a few tens of meters in diameter. Larger silicic lava flows are exemplified at C rater Lake by the preclimactic rhyodacite flows such as Cleetwood, Llao Rock, Grouse Hill, and Redcloud Cliff. They were preceded by plinian eruptions that resulted in tephra fall asfar as several hundred kilometersfrom their vents. These eruptions were fed by the climactic magma chamber, which contained a large volume of silicic magma at the time. The present magma system is unlikely to have accumulated such a large volume of eruptible magma in the 7,700 years since the climactic eruption (see Another large volume or caldera-forming eruption?). Consequently, we do not consider eruptions of this magnitude to belikely in thenext few thousand years. A smaller silicic eruption within a few kilometers of the cal dera cannot be ruled out. Wehave not designated a specific hazard zone for this type of eruption on plate 1 because it would approximately coincide with Proximal $\mathrm{H}$ azard Z $\mathrm{Z}$ one PB.

\section{HAZARDS OF LAHARS (VOLCANIC DEBRIS FLOWS) AND THEIR RUNOUT FLOWS}

Lahars are rapidly flowing mixtures of water and rock debris that originate from volcanoes. They can range from dense, viscous slurries resembling wet concrete (containing about two thirds sediment and one third water by volume) to turbulent muddy floods that carry relatively little sediment. Lahars can develop from (1) water-saturated debris avalanches or (2) originate from erosion and incorporation of sediment or rock debris by large, rapidly released volumes of water. Although a major concern at $C$ ascade volcanoes such as M ount Rainier, the first type of lahar is not considered possible at Crater Lake because the 
main volcanic edifice of $M$ ount $M$ azama, which would have been the potential source for a debris avalanche, was engulfed 7,700 years ago by collapse of $C$ rater Lake caldera. The second type of lahar would be possible if lake water were rapidly ejected from the caldera during a volcanic eruption or if hot volcanic deposits melted a large amount of snow.

Lahars are channeled into valleys as they move downhill under theforce of gravity. They can get bigger as they move downstream by incorporating additional sediment and water en route (called bulking), commonly increasing in volume by a factor of 3 to 5 . The amount of water available limits the potential size of a lahar. Lahars travel faster than water in channels of similar depth and slope. Their velocities may be as great as $20 \mathrm{~m} / \mathrm{s}$ (45 mph) in steep channels close to a volcano but diminish to 5 to $10 \mathrm{~m} / \mathrm{s}$ (about 10 to 20 $\mathrm{mph}$ ) in the broader, more gently inclined channels farther away. In relatively narrow canyons, lahars may be many tens of meters deep. As they get farther from a volcano, lahars spread out in the wider, flatter river valleys, often burying roads, bridges, and buildingswith their deposits. Lahars commonly travel tens of kilometers (tens of miles), and the largest havetravelled $100 \mathrm{~km}$ (60 miles) or more from Cascade Range volcanoes.

\section{Potential for lahars at Crater lake}

Lahars could be generated as ejected lake water or melted snow mobilized the poorly-consolidated parts of the climactic eruption deposits in the drainages radiating from $M$ ount $M$ azama. The mantle of climactic eruption deposits is up to $\sim 100 \mathrm{~m}$ thick and forms an ample source of sediment for lahars. These deposits include (1) poorly-consolidated, sandy pyroclastic-flow veneer and coarselithic breccia (rocky debris) on upland surfaces and in the heads of valleys, (2) pumiceous pyroclastic-flow deposits partially filling valleys below $\sim 1,800 \mathrm{~m}(\sim 6,000$ feet $)$ elevation, and (3) well-sorted pumice-fall deposits on hills east of the caldera. These materials are porous and permeable, and the unsaturated portions of such deposits probably would rapidly absorb substantial amounts of water emplaced upon them. If water is supplied faster than it can be absorbed, the excess will run off. M oreover, the deeper portions of these deposits commonly are water saturated, limiting their ability to absorb additional water.

Thereare many cases of volcanic melting of snow or ice, expulsion of water from a crater lake during a volcanic eruption, failure of a natural dam, or storm runoff causing lahars on the flanks of volcanoes in which volcanic deposits have been the source of sediment. $M$ ount Pinatubo, Philippines, isa recent examplewhere spectacular damage was wrought by such lahars on agricultural land, communities, and infrastructure. These granular (noncohesive) lahars begin as water flows over new pyroclastic deposits. Thewater entrains sediment until a debris flow is formed. Farther downstream, theflow wave is progressively diluted and transforms into hyperconcentrated flow (20 to 60 percent sediment by volume) and, finally, into normal streamflow with sediment concentrations below 20 percent. The granular nature of the flow reflects the entrainment sediment that hasfew particlesin theclay $(<0.004 \mathrm{~mm})$ and silt $(0.004-0.0625 \mathrm{~mm})$ size fractions. These flows characteristically attenuate rapidly downstream, but the hyperconcentrated phase can persist for tens of kilometers.

\section{Definition of Lahar HAZARd Zone}

The boundaries of the Lahar $\mathrm{H}$ azard Zone ( $\mathrm{LA}$ on plate 1) were determined as in flood-hazard mapping in arid and semi-arid regions. The Lahar $\mathrm{H}$ azard Zone includes any area potentially inundated by flows of the magnitudes estimated below. A lahar generated on the upper slope of $M$ ount $M$ azama would be expected to quickly bulk to a debris flow but would attenuate continuously with decreasing slope as flow is lost through deposition of sediment and is not replaced by tributary inflows. M eteorologic flood hazards would surpass those of lahars from M ount M azama at low elevations where flow spreads on broad alluvial reaches of low and decreasing slope and tributary inflow adds to the flow wave. Thus, areas farther from C rater Lake, where exceptional meteorologic floods will be a more significant hazard than floods and lahars related to volcanic activity, are excluded from the Lahar $\mathrm{H}$ azard Zone. 


\section{Potential Size and Flow Velocity of Lahars at Crater lake}

We can make an educated guess of the size and properties of potential lahars at $C$ rater $L$ ake by analogy with documented events at other volcanoes. The analysis presented in table 1 is based on a 1982 lahar at M ount St. H elens (Scott, 1988) and several laharsfrom Ruapehu Volcano, N ew Zealand (N airn and others, 1979; Ruapehu Surveillance Group, 1996; S.J. Cronin, written commun., 1996).

Ruapehu is an andesite composite volcano with a crater $0.5 \mathrm{~km}$ in diameter. A $9 \times 10^{6} \mathrm{~m}^{3}$ (cubic meters) lake (also called Crater Lake) occupied the active vent at 2,540 m altitude prior to 1995. Numerous past eruptions have catastrophically displaced lake water, which probably transformed to debris flows and their hyperconcentrated runouts. At least $1.6 \times 10^{6} \mathrm{~m}^{3}$ of water and lake deposits were ejected by hydromagmatic explosions in a 1975 eruption, resulting in an $8 \mathrm{~m}$ fall in lake level ( $\mathrm{N}$ airn and others, 1979). Recorded discharges in downstream drainages reached $5,000 \mathrm{~m}^{3} / \mathrm{s}$ and flow velocities as high as $12 \mathrm{~m} / \mathrm{s}$ were estimated (Nairn and others, 1979). Estimated flow volume indicated substantial bulking of the flow. From data for the 1953, 1975, and 1995 flows at Ruapehu Volcano and the 1982 flow at M ount St. Helens, we can synthesize the dynamics and behavior of a flow appropriate for planning and design purposes at $\mathrm{C}$ rater Lake (table 1). The greater size of $C$ rater $\mathrm{L}$ ake, 0 regon, ( $\sim 9 \mathrm{~km}, 0$ regon, vs. $0.5 \mathrm{~km}$ diameter, $\mathrm{N}$ ew Zealand) may represent a greater hazard, but more probably the greater volume and depth would absorb a significant part of the energy of an explosive event. There should be ample warning to prepare for noncohesive lahars because any plausible scenario for their generation at C rater Lake is linked to renewed volcanic activity that should be preceded by detectable seismicity.

\section{REGIONAL VOLCANISM}

The $C$ ascade $R$ ange is known for large volcanoes that have been active for periods of tensto hundreds of thousands of years, among them M ount M azama, the volcano in which $C$ rater Lakecal dera formed. Far more numerous in northern California, 0 regon, and southern Washington, however, are smaller shield volcanoes, cinder cones, fissure vents, and lava domes that are manifestations of regional volcanism. Each of these erupted for brief periods in geologic terms, generally in a single episode. Compositions include the entire range from basalt to andesite, with a corresponding variety of eruptive styles and products; the most common lava type is basalt. $\mathrm{H}$ azards arise mainly from tephra falls and lava flows. Lava flows may travel tens of kilometers downslope but travel sufficiently slowly that they pose a threat only to structures and property. Life-threatening pyroclastic eruptions are possible when magma interacts with shallow ground water in wet areas, producing surges or pyroclastic flows. A reas affected by such pyroclastic activity tend to be limited to a few square kilometers. In addition, the region downwind may experience tephra fall.

Crater Lake lies in a part of the Cascades where the belt of $Q$ uaternary volcanoes is comparatively narrow, about $30 \mathrm{~km}$ from west to east (fig. 1, plate 1; Guffanti and Weaver, 1988). For purposes of hazard assessment for theimmediateC rater Lakearea, consider the region between approximately latitudes $42^{\circ} 48^{\prime}$ and $43^{\circ} 05^{\prime}$, that is, $\sim 11 \mathrm{~km}$ north and south of the caldera $\operatorname{rim}\left(\sim 1,100 \mathrm{~km}^{2} ; \sim 1,040 \mathrm{~km}^{2}\right.$ excluding the caldera). It is important to appreciate that $M$ ount $M$ azama itself, dacite and rhyodacite vents related to $M$ azama, and vents within the caldera are excluded from table 2. Some eruptive episodes are represented by several approximately coeval, nearby vents. For example, the three postglacial vents at Castle Point lie in close proximity to one another. They produced related basaltic lava and were active during a single period of at most a few years (age bracketed between 8 and 13 ka; considered to be $<10 \mathrm{ka}$ in table 2$)$. The three vents thus represent a single eruptive episode. In addition, paleomagnetic studies and $\mathbf{K}-\mathbf{A r}$ dating have established that eruptive episodes have not been uniformly spaced in time. We have given estimates of the average number of episodes per 1,000 years in table 2. The episodes varied widely in volume of products and number of vents. Because younger lava flows tend to obscure older ones, the record is much less complete for vents and episodes 100-1,000 ka in age. Theaveragenumber of known episodes per 1,000 years is much smaller for this age range than for the $<10 \mathrm{ka}$ and 10-100 ka intervals. 
Table 1.- Volumeand flow properties of a hypothetical lahar at Crater Lake based on events at M ount St. H elens, Washinton, and Ruapehu Volcano, N ew Zealand

$\left[\mathrm{m}^{3}\right.$, cubic meters; $\mathrm{m}^{3} / \mathrm{s}$, cubic meters per second; $\mathrm{km}$, kilometers; -do-, ditto]

\begin{tabular}{|c|c|c|}
\hline & $\begin{array}{l}\text { es for hypothetical } \\
\text { w at Crater Lake }\end{array}$ & Remarks \\
\hline Volume & $6 \times 10^{6} \mathrm{~m}^{3}$ & Value of 1975 flow, Ruapehu (N airn and others, 1979) \\
\hline Peak D ischarge & $5,000 \mathrm{~m}^{3} / \mathrm{s}$ & Value of 1975 flow, Ruapehu (N airn and others, 1979) \\
\hline $\begin{array}{l}\text { Velocity on edifice } \\
\quad(0-6 \mathrm{~km})\end{array}$ & $15-20 \mathrm{~m} / \mathrm{s}$ & $\begin{array}{l}\text { Velocity estimated for } 1995 \text { flow on flank- } \\
\text { W hakapapaiti Stream, Ruapehu (Ruapehu } \\
\text { Surveillance Group, 1996) }\end{array}$ \\
\hline $\begin{array}{l}\text { Velocity of runout } \\
\quad(6-16 \mathrm{~km})\end{array}$ & $10 \mathrm{~m} / \mathrm{s}$ & $\begin{array}{l}\text { Based on velocities of 1953, 1975, and } 1995 \text { flows at } \\
\text { Ruapehu and } 1982 \text { flow at M ount St. H elens }\end{array}$ \\
\hline $\begin{array}{l}\text { Velocity of runout } \\
\quad(16-40 \mathrm{~km})\end{array}$ & $6 \mathrm{~m} / \mathrm{s}$ & $\begin{array}{l}\text { Based on velocities of 1953, 1975, and } 1995 \text { flows at } \\
\text { Ruapehu and } 1982 \text { flow at M ount St. H elens }\end{array}$ \\
\hline $\begin{array}{l}\text { D istance for bulking } \\
\text { to debris flow }\end{array}$ & $<3 \mathrm{~km}$ & $\begin{array}{l}\text { Based on behavior of } 1995 \text { flows at Ruapehu and } 1982 \\
\text { flow at M ount St. H elens }\end{array}$ \\
\hline $\begin{array}{l}\text { Lahar-runout distance as } \\
\text { hyperconcentrated flow }\end{array}$ & $40 \mathrm{~km}$ & $\begin{array}{l}\text { Based on behavior of } 1995 \text { flows at Ruapehu and } 1982 \\
\text { flow at M ount St. H elens }\end{array}$ \\
\hline
\end{tabular}

\section{Probability of a Future Volcanic Eruption}

Estimating the probability of a volcanic eruption occurring within a hazard zone requires not only knowledge of eruptive frequency in the past but also assumptions about the regularity of eruptions in time and their distribution within the area in question. Lacking age information for every vent, we treat the opening of new regional volcanic vents as a random process. We assume that regional volcanism has no memory of previous events such that the process has a Poisson distribution. This may not be true of large, central-vent volcanoes such as M ount Rainier or ancestral M ount M azama, which have erupted many times from the same conduit system. The probability of an eruption occurring somewhere in the stated region at a new vent during a specified number of years, an exponential function, reduces to simply the average recurrenceratetimes the length of the period of interest for time periods that are short (tens of years) relative to the average recurrence interval (thousands of years).
O $n$ the basis of the total number of eruptive episodes in the past $\sim 100,000$ years, exclusive of M ount $M$ azama, the average recurrence interval is about 10,000 years. The annual probability of an eruption occurring near $C$ rater $L$ ake, then, is around one chance in 10,000 , or $10^{-4}$, and the 30 -year probability is about one chance in 330 , or $3 \times 10^{-3}$. These estimates are, at best, very approximate because volcanic eruptions are triggered by the interplay of complex processes and there is no guaranteethat events occurring in the future will adhere to the simplistic model used to estimate probabilities.

\section{hazard Zones for Regional Volcanoes}

$\mathrm{H}$ azard zones delineated on plate 1 are defined on the basis of locations of volcanic vents active during the past onemillion years. Zoneboundaries are drawn $\sim 3 \mathrm{~km}$ outboard of the region of known vents on the assumption that new vents are unlikely to erupt farther than $3 \mathrm{~km}$ from existing volcanoes. $N$ ote that the 
Table 2.- N umbers of known basalt, basaltic andesite, and andesite volcanic vents and eruptive episodes outside Crater Lake caldera and exclusive of M ount M azama between approximately latitudes $42^{\circ} 48^{\prime}$ and $43^{\circ} 05^{\prime}$

\begin{tabular}{cccc}
\hline $\begin{array}{c}\text { Age range } \\
k a^{*}\end{array}$ & $\begin{array}{c}\text { N umber of } \\
\text { vents }\end{array}$ & $\begin{array}{c}\text { N umber of } \\
\text { episodes }\end{array}$ & $\begin{array}{c}\text { Episodes per } \\
1,000 \text { years }\end{array}$ \\
\hline 10 & 3 & 1 & 0.1 \\
$10-100$ & 23 & 13 & 0.14 \\
$100-1000$ & 41 & 28 & 0.03 \\
\hline
\end{tabular}

${ }^{* 1} \mathrm{ka}=1000$ years Before Present (1950 AD).

hazard zones represent likely vent locations. The extent of lava flows or tephra falls will vary depending on eruption location (local topography), rate, and duration. Lava may flow beyond the limits of thehazard zones. The transportation corridor east of C rater Lake $\mathrm{N}$ ational Park could be disrupted by even a small tephra eruption because prevailing winds probably would carry tephra in that direction. Boundaries are straight lines because there are insufficient vents to justify more irregular shapes. Likewise, some boundaries have been drawn to coincide with county lines or to include cultural features (e.g., parts of highway 97) to minimize ambiguity in application.

Regional $\mathrm{H}$ azard Zone $\mathrm{RH}$ contains all vents $<100,000$ years in age. In the vicinity of Crater Lake, as described above, the annual probability within this zone is thought to be roughly $10^{-4}$ or a 30 -year probability of $3 \times 10^{-3}$. N orth of latitude $43^{\circ} 05^{\prime}$ and south of latitude $42^{\circ} 48^{\prime}$ within Zone RH there is less information on the history of volcanism but, nevertheless, the annual probability of an eruption is believed to belower than in theimmediate C rater Lake area. East of Zone RH is Regional $\mathrm{H}$ azard Zone RL, a zone where eruption probability is considered lower than in Zone RH becauseit contains only ventsbelieved to be between 100,000 and 1,000,000 years in age. $\mathrm{H}$ ere the annual probability of an eruption occurring between latitudes $42^{\circ} 48^{\prime}$ and $43^{\circ} 05^{\prime}$ is judged to be of order 1 in 100,000 , or about $10^{-5}$, or a 30 -year probability of $3 \times 10^{-4}$. Presumably, the annual probability is no greater in the parts of Zone RL north or south of the $42^{\circ} 48^{\prime}$ to $43^{\circ} 05^{\prime}$ band. O utside of these hazard zones there are no known volcanic vents younger than 1,000,000 years old and the probability of an eruption is believed to be negligible.

Theprobabilitiesquoted above arefor an eruption somewhere in a regional hazard zone. As any eruptive episode will cover only a small part of the zone with lava or tephra, the probability of a given area within the zone being affected in a particular time interval is substantially less than the probability of an eruption occurring somewhere within the zone.

\section{EVENTS OF HIGH CONSEQUENCE BUT LOW PROBABILITY}

Three types of events that may be considered possible at C rater Lake but very unlikely in the next few centuries are a large pyroclastic eruption, sudden release of lethal $\mathrm{CO}_{2}$ from the lake, and catastrophic draining of the lake. These are discussed below for completeness and because the consequences of any one of them would be significant.

\section{ANother large Volume or Caldera- FORMING ERUPTION?}

Theclimactic eruption of $M$ ount $M$ azama, during which $C$ rater Lake caldera collapsed, took place $\sim 7,700$ years ago (calendar years, based on radiocarbon age of 
$6,845 \pm 50{ }^{14} \mathrm{C}$ years B.P.; Bacon, 1983). This was the largest eruption in the $C$ ascades in the last $\sim 400,000$ years, explosively venting $\sim 50 \mathrm{~km}^{3}$ of magma during perhaps only a few days. Theproducts of the climactic eruption are dominantly rhyodacite pumice and ash. Perhaps 10 percent of the total is andesite and crystalrich "scoria" largely ejected late in the eruption. The compositionally-zoned eruption products indicatethat relatively low-density rhyodacitic magma overlay hotter, denser andesitic magma and accumulated crystals deeper in the climactic magma chamber.

Tephra fall from the climactic eruption reached into southern $\mathrm{C}$ anada and pyroclastic flows traveled down the Rogue and U mpqua Rivers, and other drainages, as much as $70 \mathrm{~km}$ from $M$ ount M azama. The maximum extent of the pyroclastic-flow deposits of the climactic eruption, not to be confused with a modern hazard zone boundary, is shown on plate 1. The area devastated as a result of the eruption exceeds that bounded by the limit of pyroclastic-flow deposits shown on plate 1 . The eruption began with hydromagmatic explosions leading shortly thereafter to a high plinian column from a single vent in what is now the northeast quadrant of the caldera, north of the summit of old M ount M azama. A major pumice fall deposit extended in a northeast direction, downwind at the time. Astheeruption proceeded, the eruption rate increased, causing the high column to eventually collapse as it ceased to be buoyant in the atmosphere. At this time, at least four valley-hugging pyroclastic flows descended the north and east flanks of M ount M azama and left a deposit known as the W ineglass Welded Tuff. This phase of the eruption ended as the caldera began to collapse and multiple vents opened around the subsiding block. From these vents, eruption columns fed highly-mobile pyroclastic flows that descended on all sides of M ount M azama, partially filling all valleys and spreading out across lowlands (plate 1). Theresult of the climactic eruption was transformation of the volcano from a large, snowcapped composite cone to a 1,200-m-deep caldera basin, drastic modification of all drainages nearby, and annihilation of all life forms for at least $30 \mathrm{~km}$ in all directions from M ount M azama.

In the 200 years prior to the climactic eruption, there had been two smaller rhyodacitic plinian eruptions, each followed by sluggish emplacement of a thick rhyodacitic lava flow (Llao Rock and Cleetwood flows). The younger of these flows, Cleetwood, was still hot when the climactic pumice fell on its surface. Although there would have been vigorous seismicity before each of these eruptions and the climactic eruption, the magnitude of the climactic event might not have been anticipated at its onset. The stage was clearly set for a voluminous eruption, however, as the geologic record indicates only rhyodacitic eruptions from the general area of M ount M azama in the preceding 20,000-25,000 years. The eruptive history thus records growth of the shallow magma chamber approximately beneath the present caldera.

Is a shallow magma chamber still present and is another caldera-forming eruption likely in the next few centuries? The geologic evidence suggests that most of the gas-charged rhyodacitic magma was ejected in, or crystallized following, the climactic eruption. Virtually all of the postcaldera lava is andesite which probably would not have been able to erupt had a large amount of lower density rhyodacite remained molten in the subsurface. The small postcaldera rhyodacite dome appears to be related to cooling and crystallization of the magma batch which had earlier produced the postcal dera andesites of the central platform, M erriam Cone, and W izard Island (fig. 3) rather than being left over from the climactic chamber. Rhyodacitic magma apparently accumulated in the climactic magma chamber at a rate of $\sim 2 \mathrm{~km}^{3} / 1,000 \mathrm{yr}$. If the postcaldera rhyodacite reflects the cooling of the last magma emplaced in the upper $10 \mathrm{~km}$ of the crust, then sufficient magma for a voluminous, explosiveeruption will not accumulate for many thousands of years. A less likely situation would be that the postcaldera rhyodacite represents the onset of silicic magma accumulation, in which case as much as $10 \mathrm{~km}^{3}$ of magma might have accumulated in the last $\sim 5,000$ years. Thisamount would be sufficient to feed a major pyroclastic eruption (e.g., M ount Pinatubo, 1991) but probably would not lead to caldera collapse. In conclusion, we consider the annual or 30-year probability of a major silicic pyroclastic eruption to be low and the probability of a caldera-forming eruption to be negligible. 


\section{Sudden Gas Release from Crater lake}

The August 12, 1986, sudden release of $\sim 1 \mathrm{~km}^{3}$ of $\mathrm{CO}_{2}$ gas from Lake $\mathrm{N}$ yos in $\mathrm{C}$ ameroon resulted in death of at least 1,700 people by asphyxiation (Kling and others, 1987). The source of $\mathrm{CO}_{2}$ at Lake $\mathrm{N}$ yos was prolonged degassing of subsurface magma. This event drew attention to the potential for dissolved lethal gas to accumulate in the deepest parts of volcanic crater lakes. D epressurization of this water if the lake overturns suddenly results in rapid exsolution of the gas and its liberation to the atmosphere. The high density of cold $\mathrm{CO}_{2}$ relative to ambient air allows the gas cloud to flow down topographic depressions and accumulate locally.

C rater Lake does not appear capable of producing a disastrous release of $\mathrm{CO}_{2}$. Theinput of thermal fluid through the floor of $\mathrm{Crater} L$ ake carries with it dissolved $\mathrm{CO}_{2}$ in the form of carbonic acid, but most of the added carbon is in bicarbonate (Collier and others, 1991). Carbon and helium isotope studies indicate a magmatic source for the $\mathrm{CO}_{2}$ input. The added carbonic acid is mixed with lake water in the deeper part of lake, reducing concentrations to fairly low levels. The upper $200 \mathrm{~m}$ of $\mathrm{C}$ rater Lake overturns and equilibrates with atmospheric gases twice a year. Any excess dissolved $\mathrm{CO}_{2}$ (as carbonic acid) comes out of solution but does not accumulate in lethal concentration. Between $200 \mathrm{~m}$ and maximum depth, lake water has been shown to mix completely with the upper portion of the lake over a period of 2.5 to 3.5 years (M cM anus, 1992). In this process, the bottom part of thelake becomes re-oxygenated by equilibrating with oxygenated surfacewater. At thesametime, higher concentrations of dissolved $\mathrm{CO}_{2}$ are lowered by mixing with water containing only atmospheric concentrations of dissolved $\mathrm{CO}_{2}$. Thus, $\mathrm{Crater} L$ ake has a source of elevated $\mathrm{CO}_{2}$, but the possibility of buildup of large amounts of dissolved $\mathrm{CO}_{2}$ is prevented by the mixing processes in the lake. The mixing process in the deep lake is driven by heating of lake water through input of the thermal fluid that carries the dissolved $\mathrm{CO}_{2}$. Any change in the thermal fluid input could affect the mixing processes in the deep lake. The state of the deep lake should continue to be monitored to detect if the mixing process changes.

\section{CATASTROPHIC FloOd OR LAHAR From Drainage of Crater lake}

Crater Lake contains $17 \mathrm{~km}^{3}$ of water (Phillips and Van D enburgh, 1968). Should the caldera wall fail and allow the lake to drain, the ensuing flood of water, rock, and remobilized pyroclastic debris would be devastating. In order for C rater Lake to breach its walls the water level would have to rise dramatically or the wall would have to fail. At its lowest elevations at Kerr N otch, W ineglass, and northwest of Round Top, the caldera rim is $\sim 165 \mathrm{~m}$ above the lake. N othing short of major volcanic activity or drastic change in climate is likely to cause such a rise in lake level. The amount of rock that would haveto be removed by wall failure in order for the lake to overflow into one of the valleys on the flanks of $M$ ount $M$ azama, assuming a minimum width of $500 \mathrm{~m}$, is on the order of $0.1 \mathrm{~km}^{3}$. Even if the lake should overflow, whether outflow becomes catastrophic would depend on the rate of downcutting and breach enlargement. A range of possible maximum discharges varying by two orders of magnitude $\left(1.3 \times 10^{5}\right.$ to $\left.3.9 \times 10^{7} \mathrm{~m}^{3} / \mathrm{s}\right)$ can be estimated as theoretically possible by analogy with catastrophic drainage of a prehistoric lakein Aniakchak caldera, Alaska (Waythomas and others, 1996). H owever, there does not appear to be a mechanism by which breach of the walls of $C$ rater Lake caldera could be accomplished. An extremely low level of risk from catastrophic lake drainage is understood to exist throughout all downstream lowlands around M ount M azama.

\section{PROTECTING CRATER LAKE NATIONAL PARK AND SURROUNDING COMMUNITIES FROM VOLCANO HAZARDS}

The N ational Park Service, local communities, businesses, and citizens can undertake several actions to mitigate the effects of future eruptions at and near C rater Lake. Long-term hazards mitigation includes using information about volcano hazards when making decisions about land use and the siting of critical facilities, housing, and rights-of-way for transportation and utilities. D evelopment can (1) avoid areas judged to have an unacceptably high risk, (2) be planned in 
such a way as to reduce the level of risk, or (3) include engineering measures to mitigate risk. Limits on development and land use within C rater LakeN ational Park and the ability of the $\mathrm{N}$ ational Park Service to control access simplify volcanic risk mitigation. In addition, the relatively low probability of lahars originating on $\mathrm{M}$ ount $\mathrm{M}$ azama and flowing down the surrounding valleys limits the degree to which communities outside the park need to prepare for such unlikely events. $\mathrm{N}$ ote that in the $\mathrm{C}$ rater Lake region, seismic risk may be as significant as volcanic risk (see Preparing for an earthquake affecting the $C$ rater Lake region).

When volcanoeserupt or threaten to erupt, shortterm emergency responses are needed. Such responses will be most effectiveif citizens and public officials have an understanding of volcano hazards and have planned the actions needed to protect communities. Because the time can be short between onset of precursory activity and an eruption (daysto months), and because some hazardous events can occur without any warning, suitable emergency plans should be made beforehand. Public officials need to consider such issues as public education, communications, and evacuation planning. The last deserves special consideration at C rater Lake because of the limited road access to the heavily used south rim of the caldera. Although the number of people located there at any given time is not great, disruption of the road system could make rapid evacuation challenging.

Business owners, school officials, and individuals should also make plans to respond to volcano emergencies. Planning is not only prudent, it is vital. O nce an emergency begins, public resources can often be overwhelmed, and citizens may need to provide for themselves and make their own informed decisions. The Red Cross recommends that certain basic items be kept in homes, cars, and businesses in case of emergency, such as portable radios, flashlights, firstaid kits, emergency food and water, etc. These items may prove very valuable in a volcano emergency. Two important additional items are (1) knowledge about volcano hazards and (2) an emergency plan of action. If you work or reside within the proximal hazard zone, know how to get safely out of the zone quickly and be aware that hazard zone boundaries are not sharp lines on theground. O ncean eruption begins, the proximal hazard zone can be affected by a pyroclastic surge so rapidly that escape may not be possible. If you are located within a hazard zone for lahars, know how to move safely to high ground rapidly realizing that moving quickly on foot to the highest ground in the vicinity may be the best strategy. A safe height abovea river channel depends on several factors: size of the flow, distancefrom the volcano, and shape of the valley. If you decide to evacuate downvalley, realize that these flows can travel as fast as $20 \mathrm{~m} / \mathrm{s}$ (45 mps). Be sure that you don't move into a more hazardous area. Be aware that others also may be trying to evacuate at the same time as you are, and escape routes on roads may become dangerously congested. For example, if highway 97 becomes closed for any reason (such as tephra fall), highway 62 can become choked with redirected traffic.

\section{EARTHQUAKES}

G round shaking from earthquakes on local faults and on the distant Cascadia subduction zone poses a hazard to structures at $\mathrm{C}$ rater Lake. Earthquakes may trigger landslides and rock falls that may not only threaten roads and trails but also may cause destructive waves on Crater Lake itself. Below we consider the historic record and the geologic evidence for the types of earthquakes likely to affect the $C$ rater Lake area.

\section{SEISMICITY}

There is a significant variation in rates of modern seismicity along the $C$ ascade R ange, with the area south of $\mathrm{M}$ ount $\mathrm{H}$ ood in $\mathrm{O}$ regon being quiet compared to other parts of the Cascades (Weaver, 1989). For example, a four station array along with an ultraportable outlier station operated in the summer of 1970 at Crater Lakefound that therewere fewer small events at $C$ rater Lake than at $\mathrm{M}$ ount $\mathrm{H}$ ood and that no recorded events were deeper than $12 \mathrm{~km}$ (Westhusing, 1973). Prior to the $1993 \mathrm{~K}$ lamath Falls earthquakes (see below), seismometers have been too few and too distant from Crater Lake to detect and accurately locate small earthquakes. There is, however, a sparse record of seismicity at Crater Lake and its vicinity (fig. 4 and table 3). The largest event took place in 1920 before there were many seismometers in 0 regon. It is known 
Table 3.- Seismicity in the vicinity of Crater Lake, O regon.

\begin{tabular}{cllllll}
\hline Date & $\begin{array}{l}\text { Time } \\
\text { UTC }\end{array}$ & $\begin{array}{c}\text { Latitude } \\
\text { (degrees) }\end{array}$ & $\begin{array}{c}\text { Longitude } \\
\text { (degrees) }\end{array}$ & $\begin{array}{c}\text { Depth } \\
\text { (kilometers) }\end{array}$ & M & Comment \\
\hline 20/04/14 & $11: 45$ & 42.92 & 122.10 & & $4+$ & 3 shocks. Intensity V at Fort K lamath \\
$47 / 10 / 11$ & $16:$ & 42.75 & 122.00 & & 3.7 & \\
$47 / 10 / 12$ & $19:$ & 42.67 & 122.08 & & $1+$ & \\
$47 / 10 / 14$ & $03: 30$ & 42.67 & 121.92 & & $1+$ & \\
$82 / 06 / 19$ & $08: 23$ & 42.904 & 122.083 & $0.02 *$ & 1.7 & Felt \\
$93 / 09 / 21$ & $12: 50$ & 42.575 & 122.181 & $0.02 *$ & 1.9 & \\
$94 / 01 / 26$ & $12: 33$ & 42.850 & 122.295 & 42.07 & 2.0 & Low frequency event \\
$94 / 01 / 28$ & $07: 37$ & 42.533 & 122.058 & 4.55 & 1.3 & \\
$94 / 05 / 19$ & $03: 22$ & 42.673 & 122.047 & 6.28 & 1.7 & \\
$94 / 05 / 19$ & $14: 35$ & 42.662 & 122.054 & 9.29 & 1.6 & \\
$94 / 05 / 20$ & $20: 05$ & 42.524 & 121.680 & $0.02 *$ & 2.4 & Explosion? \\
$94 / 05 / 27$ & $18: 56$ & 42.554 & 121.614 & 17.82 & 2.1 & \\
$94 / 12 / 29$ & $00: 21$ & 42.886 & 122.120 & 1.48 & 2.3 & \\
$94 / 12 / 29$ & $00: 22$ & 42.904 & 122.113 & 1.11 & 2.6 & Felt \\
$94 / 12 / 29$ & $00: 40$ & 42.892 & 122.116 & $1.87 \dagger$ & 2.4 & Felt \\
$95 / 08 / 13$ & $14: 36$ & 42.657 & 122.056 & $9.00 \dagger$ & 2.0 & \\
$95 / 08 / 13$ & $16: 18$ & 42.661 & 122.047 & 4.28 & 2.1 & \\
$95 / 08 / 13$ & $16: 22$ & 42.666 & 122.040 & $0.76 \dagger$ & 2.0 & \\
\hline
\end{tabular}

Time is Coordinated Universal Time (UTC). For Pacific Standard Time, subtract 8 hours. For Pacific Daylight Time, subtract 7 hours.

* D epth fixed to an arbitrary value.

$\dagger M$ aximum number of iterations exceeded. Location and depth are arbitrary.

M - An estimate of the local Richter magnitude. For events after $1982, \mathrm{M}$ is the coda-length magnitude $\mathrm{M}_{C}$.

For more information see Bacon and $N$ athenson (1996, table 2)

to have been felt at Intensity $V^{3}$, and had an estimated magnitude of $4+$. The earthquake's location is quite uncertain, though it is thought to have been near $C$ rater Lake. In 1947 there was an event with estimated magnitude of 3.7 south of Crater Lake near the town of Fort K lamath. O ne felt event in 1982 occurred near Crater Lake while a temporary array of seismic stations was deployed in 0 regon (Kollmann and Zollweg, 1984). Relocation of this event by
R.S. Ludwin (written commun., 1996) places it closer to $C$ rater Lake and reduces its magnitude to 1.7 from the 2.5 calculated by Kollmann and Zollweg (1984).

South of the area of figure 4 and $-60 \mathrm{~km}$ south of $C$ rater Lake, two strong earthquakes, $M=5.9$ and 6.0, occurred September 20, 1993, followed by hundreds of aftershocks during the succeeding weeks (the "K lamath Falls" earthquakes). The main events had hypocentral depths of $\sim 9 \mathrm{~km}$ and apparently took

3 M odified M ercalli Intensity Scale V: "Felt outdoors; direction estimated. Sleepers wakened. Liquids disturbed, some spilled. Small unstable objects displaced or upset. D oors swing, close, open. Shutters, pictures move. Pendulum clocks stop, start, change rate." 
place on a north-northwest-trending normal fault inclined $\sim 4^{\circ}$ to the northeast (Braunmiller and others, 1995). These earthquakes caused rock falls and small landslides (largest $\sim 300 \mathrm{~m}^{3}$ ) from road cuts, quarries, and steep bluff faces asfar as $29 \mathrm{~km}$ from theepicentral area (Keefer and Schuster, 1993). Subsequent to the K lamath Falls earthquakes of 1993, telemetered instruments were added to monitor ongoing seismicity (University of Washington, 1993), and locations and detection limits for earthquakes in the vicinity of $\mathrm{C}$ rater Lakeimproved. The 1993 event $38 \mathrm{~km}$ south of $\mathrm{Crater}$ Lake (fig. 4) took place a few hours after the second K lamath Falls earthquake (a magnitude 6.0) and still has a considerable uncertainty of location. The map of earthquakes in Washington and O regon from 1872-1993 (Goter, 1994) shows a scattering of seismicity stretching northward from K lamath Falls to $C$ rater Lake. The catalogue for these earthquakes (R. S. Ludwin, written commun., 1996) shows that they are preliminary locations of aftershocks from the 1993 K lamath Falls earthquakes as located by the $\mathrm{N}$ orthern California Seismic N etwork. Subsequent work has shown that the aftershocks did not extend as far north as shown on Goter's map ( $Q$ amar and M eagher, 1993).

In 1994 and 1995, there was a significant amount of seismicity near Crater Lake. D etection of the earthquakes of 1994 and 1995 may be partly a result of improved instrumentation, as the prior detection threshold for earthquakes that were not felt was probably at least $M=3$. T he event of 1 January 1994 , west of $C$ rater Lake is noteworthy in having a depth of $42 \mathrm{~km}$ and low-frequency wave form, properties atypical of tectonic earthquakes. In $\mathrm{M}$ ay, therewere two events in the vicinity of the 1947 events near Fort K lamath. In D ecember, there were three events (two felt) just south of Crater Lake. In August of 1995, there were three more events near Fort K lamath. It is possible that the recent $M=2-3$ earthquakes represent a regional increase in seismicity related to the K lamath Falls earthquakes of 1993 because thenumber of events per year has declined each year since 1993. The area around Klamath Falls in the K lamath graben has had significantly more seismicity in the last 50 years than has C rater Lake (see list in Sherrod, 1993).

Faults with normal (mainly vertical) displacement abound in the $C$ rater Lake region and the contiguous
Basin and Range province to the east of the $C$ ascades (fig. 1 and 4; plate 1; Pezzopane and Weldon, 1993). M ost of these faults trend north-south to northnorthwest-south-southeast. Faults are more easily recognized by topographic expression in theeastern half of the area where no relatively young volcanic rocks occur. Faults cutting the youthful lava flows of the forested $C$ ascades are less obvious because fault offsets are smaller than in the older rocks of the sparsely vegetated landscape to the east where fault scarps can be dramatically seen, as along the east side of U pper Klamath Lake (Sherrod, 1993). Young lava flows and glacial deposits in the Cascades providean opportunity for testing whether faults are potentially active, as these materials may be datable. O ffset lava flows in C rater Lake $N$ ational Park and glacial moraines at the mouths of valleys on the west side of the U pper Klamath Lake basin are described below as evidence for the recent activity of a major, through-going fault zone. Little is known about the state of faults immediately east of the Cascades and we are unaware of any detailed paleoseismic studies of faults (i.e., trenching) depicted in plate 1.

\section{West Klamath lake fault Zone}

M ount M azama lies at the north end of the fault bounded basin known as the K lamath graben. North of Klamath Falls, highway 97 skirts Upper Klamath Lake along the base of fault scarps of the east side of the graben (Sherrod and Pickthorn, 1992; Sherrod, 1993). The west side is bounded by the active West Klamath Lake fault zone (W KLFZ; $\mathrm{H}$ awkins and others, 1989). The surface expression of theW KLFZ consists of a series of normal faults trending approximately north-south. Individual faults have lengths of $10-15 \mathrm{~km}$ and displace late $Q$ uaternary lavas and glacial deposits tens of meters, generally down-tothe-east. For example, highway 62 ascends the Annie Spring fault scarp of the W KLFZ immediately north of thejunction with theroad to $C$ rater Lake. TheAnnie Spring fault originates at least as far south as Pumice Flat, passes through AnnieSpring, and continues nearly to The Watchman (fig. 2).

The consistency in age and amount of displacement on its various faults suggests that the W KLFZ merges at depth into a single through-going 



FIGURE 4. $-M$ ap showing earthquake epicenters and magnitudes. Base from figure 1. See Bacon and $N$ athenson (1996, table 2) for data sources. N ote that accuracy of epicentral locations varies widely. Earthquakes occurring in 1993 and subsequent years are more accurately located than prior events. D epths of earthquake hypocenters al so vary significantly and are not precisely known for most events. Because faults are inclined, earthquakeepicenters that do not coincide with specific mapped faults nevertheless may have occurred on a known fault zone. 
structure. The subparallel Sky Lakes fault zone cuts older lavas $-6-8 \mathrm{~km}$ west of the WKLFZ. Both of these fault zones pass through $C$ rater Lake $N$ ational Park and emerge on the north as a 10-km-wide zone of faulting that has been mapped as far as M ount Bailey (plate 1). The southern boundary of the WKLFZ is marked by a change in strike of faultsfrom north-south to north-northwest-south-southeast (south of thearea of fig. 1 and 4, plate 1). Thetotal length of theW KLFZ and itsnorthward continuation, between approximately the latitudes of Pelican Butte and M ount Bailey, is $\sim 70 \mathrm{~km}, \sim 50 \mathrm{~km}$ if thenorthern section is not included. Scarp heights in young lavas and moraines suggest that motion on theW KLFZ has occurred in events of a few meters vertical displacement and that large sections of the zone may have moved at once. The WKLFZ is analogous to other activenormal fault zones of theBasin and Range province and is capable of producing large earthquakes (e.g., C rone and others, 1991).

$M$ any of thelocated earthquakes shown in figure 4 occurred within the Klamath graben. Fault planes exposed by quarrying in the K lamath Basin have steep dips (inclinations of $\sim 60^{\circ}$ from horizontal) and appear to record mainly vertical (dip slip) displacement. Earthquake epicenters shown in figure 4 may be associated with slip at depth on specific mapped faults, given the direction of dip of the faults, focal depths of earthquakes, and imprecision of earthquake locations. The earthquakes south of C rater Lake $\mathrm{N}$ ational Park and west of latitude $122^{\circ}$ may have occurred along the W KLFZ, except the September 21, 1993 event which may have been on the Sky Lakes fault zone (plate 1).

\section{SLIP RATE AND RECURRENCE INTERVAL OF THE WKLFZ}

An estimate of the long-term slip rate on the W KLFZ near Crater Lake can be obtained from geologic mapping of offset lava flows that have been dated by the K-Ar method. For example, a dacite flow dated at $50 \pm 6$ ka appears to be offset $\sim 15 \mathrm{~m}$ vertically, down to the east, al ong the Annie Spring fault $\sim 750 \mathrm{~m}$ west of Rim Village. This result implies an average rate of vertical displacement of $0.3 \mathrm{~mm} / \mathrm{yr}$. This rateis corroborated by vertical offsets of older lava flows along the same fault up to $10 \mathrm{~km}$ south of The Watchman (table 4). In addition, a minimum displacement on the related Red Cone Spring fault northwest of the caldera (fig. 1 and plate 1) suggests a similar rate ("A" in table 4). Should the fault dip $60^{\circ}$ and have a purely normal sense of motion, the east-west tectonic extension rate would be $0.17 \mathrm{~mm} / \mathrm{yr}$ and the slip rate in the plane of the fault would be $0.35 \mathrm{~mm} / \mathrm{yr}$. This result is similar to long-term average slip rates of 0.1-0.6 mm/yr determined by Pezzopaneand Weldon (1993) for faults at the west edge of their Central O regon fault zone $\sim 100 \mathrm{~km}$ east of Crater Lake.

Estimates of slip rates on faults of the W KLFZ south of C rater Lake are consistent with our data for the AnnieSpring and Red ConeSpring faults. $\mathrm{H}$ awkins and others (1989, table 3) measured offsets in $\sim 130-150 \mathrm{ka}$ and $\sim 10-30 \mathrm{ka}$ glacial moraines and in early $\mathrm{H}$ olocene deposits at the mouths of the canyons of D ry, Sevenmile, Threemile, and C herry C reeks where they enter the K lamath graben and reported an average slip rate of $0.17 \mathrm{~mm} / \mathrm{yr}$ for the last $\sim 130,000$ years. They noted that at least one 1-2 m surface displacement event has occurred in the last 10,000 years.

Recurrence intervals are unknown for earthquakes that cause surface displacement on the W KLFZ. If all of the displacement on these faults occurred in events with, say, 1-3 m of vertical offset, significant earthquakes would be expected to recur at an average rate of one event in $\sim 3,300-10,000$ years. This inference is consistent with paleoseismic data for the Ana R iver fault $\sim 100 \mathrm{~km}$ east-southeast of $C$ rater Lake (Pezzopane and others, 1996). We cannot give a more rigorous estimate of the probability of alarge earthquake on the WKLFZ without knowledge of the time and amount of co-seismic displacement of the last event (Working Group on California Earthquake Probabilities, 1990), such as might be obtained by trenching across the fault trace.

\section{MAXIMUM EARTHQUAKE ON THE WKLFZ}

The maximum earthquake likely to occur on a fault or fault zone can be estimated from fault characteristics such as surface rupture length and downdip rupturearea. C ritical to thisanalysisisrupture length, which depends on fault zone segmentation (Schwartz and Coppersmith, 1986). Crater Lake appears to be adjacent to a segment boundary in the 
Table 4. - Fault offsets (down to the east) and average long-term sip rates along Annie Spring and Red Cone Spring faults

[m, meters; ka, kilo-annum ( $10^{3}$ years); mm/yr, millimeters per year]

\begin{tabular}{|c|c|c|c|c|c|}
\hline & Unit & Locality & $\begin{array}{c}\text { O ffset } \\
\text { m }\end{array}$ & $\begin{array}{c}\text { Age } \\
\text { ka }\end{array}$ & $\begin{array}{l}\text { Avg. slip } \\
\text { mm/yr }\end{array}$ \\
\hline A: & Basaltic andesite of Red Cone & NW of Red Cone & $>11$ & $35 \pm 4 *$ & $>0.31$ \\
\hline B: & D acite of The Watchman & W of Rim Village & $\sim 15$ & $50 \pm 6 \dagger$ & $\sim 0.30$ \\
\hline$C:$ & $D$ acite north of $C$ astle $C$ reek & W of Rim Village & $>50$ & $205 \pm 3 \dagger$ & $>0.24$ \\
\hline$D:$ & D acite of G arfield Peak & W of M azama Campground & $>67$ & 240\# & $>0.28$ \\
\hline$E:$ & Andesite of Applegate Peak & W of Rim Village & $>76$ & $250 \pm 8 \dagger$ & $>0.30$ \\
\hline $\mathrm{F}:$ & D acite of M unson Ridge & W of Annie Spring & $>45$ & $276 \pm 11 \dagger$ & $>0.16$ \\
\hline G: & Andesite of Arant Point & Arant Point & $<160$ & $297 \pm 12 \dagger$ & $\varangle 0.5$ \\
\hline $\mathrm{H}:$ & Basaltic andesite W of Arant Pt. & S of Arant Point & $>100$ & $>300 \#$ & -0.3 \\
\hline
\end{tabular}

* 40Ar/39Ar plateau age of whole rock sample by M.A. Lanphere.

$\dagger \mathrm{K}$-Ar age of whole rock sample by M .A. Lanphere.

\# Constrained by K-Ar age(s) of contiguous unit(s).

greater W KLFZ within which there is no recognized displacement of $\sim 50$ kalava flows (fig. 2, plate 1 ). The southern boundary of this segment may be coincident with the end of the W KLFZ where the faults change trend from north-south to north-northwest-southsoutheast in the epicentral area of the 1993 Klamath Falls earthquakes. This suggests a maximum possible rupture length of $\sim 50 \mathrm{~km}$. Consideration of the empirical relation between earthquake magnitude and surface rupture length (SRL) for normal faults given by Wells and Coppersmith (1994, table 1A) and a maximum $S R L$ of $50 \mathrm{~km}$ suggests a maximum earthquake of $\mathrm{M}_{\mathrm{W}}=7.1 \pm 0.3\left(\mathrm{M}_{\mathrm{W}}=7.3 \pm 0.3\right.$ for $\mathrm{SRL}=70 \mathrm{~km} ; \mathrm{M}_{\mathrm{W}}=$ magnitude based on seismic moment, the total energy released in an earthquake). This result is similar to the conclusion of $\mathrm{H}$ awkinsand others $(1989,1992)$ who evaluated the potential shaking at dam sites $50-85 \mathrm{~km}$ south-southeast of $C$ rater Lake and reported a maximum earthquake for the West Klamath Lake fault zone of $\mathrm{M}_{S}=71 / 4$ ( $\mathrm{M}_{\mathrm{S}}=$ surface wave magnitude).

If the hypocentral depths of the 1993 earthquakes are typical of the fault zone, another estimate of the maximum event can be obtained from the empirical relation between downdip rupturearea and magnitude (Wells and Coppersmith, 1994, table 1A). This suggests a maximum magnitude of $7.0 \pm 0.2$ for a maximum depth of $12 \mathrm{~km}$, dip of $60^{\circ}$, and length of $50 \mathrm{~km}$ ( 7.1 for $S R L=70 \mathrm{~km}$ ). Increasing depth to $15 \mathrm{~km}$ raises the calculated magnitude to 7.1 (7.3 for $\mathrm{SRL}=70 \mathrm{~km}$ ). In light of the uncertaintiesin the above calculations we consider our best estimate of the maximum earthquake likely to occur near $C$ rater Lake to be $\mathrm{M}_{\mathrm{L}}=71 / 4$ (table 5; $\mathrm{M}_{\mathrm{L}}=$ local magnitude).

\section{Cascadia Subduction Zone}

The Juan deFuca and $G$ orda oceanic plates move beneath the $\mathrm{N}$ orth American plate al ong the $\mathrm{C}$ ascadia subduction zone. This process generates earthquakes, such as the $M_{1}=6.7$ earthquake $\left(M_{1}=\right.$ magnitude based in Intensity) that occurred near the $C$ alifornia- $O$ regon State line on N ovember 23, 1873, and was felt from San Francisco to Portland (Ellsworth, 1990). G eologic evidence indicates that there have been very large Cascadia subduction zone earthquakes in the recent past (Atwater and others, 1995), apparently most recently in 1700 A.D. (Satake and others, 1996). The 
Table 5- $M$ aximum earthquakes magnitudes in the Crater Lake region (modified after $H$ awkins and others, 1989). $\left[M_{L}=\right.$ local magnitude; $M_{S}=$ surface wave magnitude; $M_{W}=$ magnitude based on seismic moment $]$

\begin{tabular}{lcccc}
\hline Fault & $\begin{array}{c}\text { Assumed } \\
\text { rupture } \\
\text { length, } \mathrm{km}\end{array}$ & $\begin{array}{c}\text { Assumed } \\
\text { focal } \\
\text { depth }\end{array}$ & $\begin{array}{c}\text { Epicentral distance } \\
\text { from C rater } \\
\text { Lake, km }\end{array}$ & M agnitude \\
\hline A: $\quad$ Random earthquakes & 17 & $5-10$ & 10 & $M_{L} 6$ \\
B: $\quad$ Sky Lakes fault zone & $50-70$ & $<12$ & 0 & $M_{S} 63 / 4$ \\
C: $\quad$ West Klamath Lakefault zone & & 35 & 100 & $M_{L} 71 / 4$ \\
D: $\quad$ Cascadia subduction zone & & $1-5$ & 0 & $M_{W} \geq 8$ \\
E: $\quad$ Volcanic earthquake & & & & $M_{L} 5$ \\
\hline
\end{tabular}

maximum magnitude of a great earthquake on the Cascadia subduction zoneiscertainly $\mathrm{M}_{\mathrm{W}} \geq 8$ (table 5) and evidence is mounting that the event in 1700 A.D. had $M_{w} \geq 9$ (e.g., Satake and Tanioka, 1996). Probabilities of large earthquakes could beestimated if recurrence intervals were known but data are currently insufficient (N elson and others, 1996). Probabilistic assessments of earthquake hazards in 0 regon are described in detail by G eomatrix Consultants (1995) ${ }^{4}$.

\section{VOLCANIC EARTHQUAKES}

Renewed volcanic activity would be preceded and accompanied by earthquakes. Ground motion from volcanic earthquakes (i.e., earthquakes associated with a volcano's plumbing system or occurring within the volcano itself) would be qualitatively similar to that caused by tectonic earthquakes but the maximum magnitude from a volcanic source would be expected to be considerably smaller than those estimated for purely tectonic earthquakes. For example, the largest earthquake recorded at M ount St. H elens prior to the eruption of $M$ ay 18,1980 , was the event that triggered the failure of the mountain. This earthquake had a magnitude of 5.1 and a hypocentral depth of $1.5 \mathrm{~km}$ (Endo and others, 1981). We consider $M=5$ to be a reasonable maximum value for $C$ rater Lake volcanic earthquakes (table 5). This is a significant potential source of ground shaking as volcanic earthquakes might occur beneath $C$ rater Lake itself and could have very shallow hypocenters.

\section{LANDSLIDES MAY CAUSE LARGE WAVES ON CRATER LAKE}

$M$ any park visitors descend to $C$ rater Lake along the Cleetwood trail, from whence they may travel to W izard Island and around the lake on tour boats operated by $C$ rater Lake Lodge. Four tour boats and a N PS research boat are on the lake. Structures used for boat maintenance and to house the boats during the winter are located on W izard Island. These facilities, and the people who use them, would be at risk if there were a major disturbance of the lake surface. An event that could result in such a disturbance would be failure of part of the caldera wall causing a rapidly-moving

4 Available from The N ature of the N orthwest Information Center, Suite 177, 800 N E O regon Street, Portland, OR 97232-2162. 
landslide or rock fall into thelakeor beneath its surface and which could result in one or morelarge waves that would travel rapidly across C rater Lake and impact its shore. Landslides or rock falls could betriggered within the caldera by earthquake shaking.

\section{SUBAQUEOUS LANDSLIDES}

Geologic evidence for the rapid formation of C rater Lake cal dera by catastrophic collapse during the climactic eruption of $M$ ount $M$ azama indicates that most of the caldera wall dates from that time. H owever, the bench on the south wall, informally known as C haski slide, wall-parallel lake-facing scarps near Garfield Peak, and similar faults mapped in the Sun $\mathrm{N}$ otch to Eagle Point area suggest that large blocks of the south wall have the potential to fail. N elson and others $(1988,1994)$ described a landslide deposit (fig. 3 and table 6) on the lake floor from Chaski Bay to the center of the lake that apparently formed soon after the caldera collapsed and the central platform volcano erupted but before a deep lake was present. Although other probable landslide deposits in the caldera also are thought to have been subaerially deposited and overlain by lacustrine deposits ( $\mathrm{N}$ elson and others, 1988), there area number of bathymetric features that may be subaqueous slide deposits (fig. 3 and table 6). Early lake deposits (c. 7,000 years ago) are thought to be gravity-flow deposits derived from landslides triggered by seismicity associated with postcaldera volcanism (N elson and others, 1994). We have no evidence from bathymetry or seismic profiling of large subaqueous slide deposits having formed on thecaldera floor since volcanism ceased; i.e., within the last $\sim 5,000$ years.

Extensivetalus depositsform much of the caldera wall, particularly beneath the lake surface, and these might be prone to failure by sliding. M ovement of debris down the subaqueous walls is ongoing and feeds sediment to the deep portions of the lake ( $\mathrm{N}$ elson and others, 1988). It appears unlikely that rapid mass movements of sufficient volume to displace the lake surface have occurred in at least the last few hundred years. There does not appear to beunequivocal evidence of high stands of the lake, or destruction of lichen or trees that might be caused by large waves ( $\mathrm{N}$ elson and others, 1994). W illiams (1942, p. 129), however, states that "Several years ago, G ordon $\mathrm{H}$ egeness, then on the ranger-naturalist staff, discovered diatomaceous earth [lake sediment] on W izard Island, approximately 50 feet above the surface of the lake." Assuming this report is correct, it is unclear whether this deposit formed during a high stand of the lake or was ripped up from the lake floor and deposited by a wave.

\section{How large Must an EARTHQUake be to TRIGGER LANDSLIDES?}

A possible trigger for a landslide that might generate dangerous waves would be ground shaking during an earthquake on the WKLFZ, especially the Annie Spring and Red C one Spring faults. In order to cause a wave, the avalancheor slidemust travel rapidly into or beneath the lake. There are many types of "Iandslides" that may be triggered by earthquake shaking. Those considered possible at Crater Lake include disrupted falls, slides, and avalanches of rock, soil (broadly defined as a loose, unconsolidated, or poorly cemented aggregate of particles), or snow and coherent slumpsand block slides (as defined by Keefer, 1984). Subaqueous slides are likely to consist of the same kinds of rock or soil as in subaerial slides, rather than sand or finer-grained sediments, so that we will not differentiate between the two environments for purposes of this report. M oreover, because we are concerned with falls and slides that may displace sufficient lake water to cause damaging waves, we only consider large volume landslides that move very to extremely rapidly. This eliminates coherent slides and

5 M odified M ercalli Intensity IV: "H anging objects swing. Vibration like passing of heavy trucks; or sensation of a jolt like a heavy ball striking the walls. Standing motor cars rock. W indows, dishes, doors rattle. G lasses clink. Crockery clashes. In the upper range of IV wooden walls and frame creak." M odified M ercalli Intensity VI: "Felt by all. M any frightened and run outdoors. Persons walk unsteadily. Windows, dishes, glassware broken. Knickknacks, books, etc., off shelves. Pictures off walls. Furniture moved or overturned. Weak plaster and masonry D [poor quality] cracked. Small bells ring(church, school). Trees, bushes shaken (visibly, or heard to rustle)." 
Table 6. - Approximate minimum areas, thicknesses, and volumes of probable landsides at Crater Lake $\left[\mathrm{m}^{2}\right.$, square meters; $\mathrm{m}$, meters; $\mathrm{m}^{3}$, cubic meters]

\begin{tabular}{|c|c|c|c|c|}
\hline & Slide & $\begin{array}{c}\text { Area } \\
106 \mathrm{~m}^{2}\end{array}$ & $\begin{array}{c}\text { M ean } \\
\text { thickness, } m\end{array}$ & $\begin{array}{l}\text { Volume } \\
106 \mathrm{~m}^{3}\end{array}$ \\
\hline$A:$ & South of Palisade Point & 0.066 & 20 & 1.3 \\
\hline B: & North of Castle Crest & 0.16 & 20 & 3.2 \\
\hline$C:$ & N orthwest of Skell H ead & 0.23 & 30 & 6.9 \\
\hline$D:$ & West of Sentinel Rock & 0.83 & 40 & 33 \\
\hline$E:$ & Chaski Bay (N elson and others, 1988) & 4.65 & 20 & 93 \\
\hline $\mathrm{F}:$ & Southwest of Skell H ead & 0.044 & 3 & 0.13 \\
\hline G: & Chaski Bay block above lakelevel & 0.19 & 80 & 15 \\
\hline
\end{tabular}

snow avalanches from our analysis.

Keefer (1984) provides guidelines for evaluating the potential of earthquakes of a given magnitude and epicentral distance to induce the various kinds of landslides. In terms of M odified M ercalli Intensity (M M I), a measure of local shaking, disrupted slides and falls would be expected to be common at $\mathrm{MMI} \geq \mathrm{VI}$. H owever, theminimum intensity for such occurrences would be IV ${ }^{5}$. The smallest local earthquake in Keefer's study that triggered rock falls and slides had $\mathrm{M}_{\mathrm{L}}=4.0$. Thus, the maximum volcanic earthquake, with epicenter at Crater Lake, would be expected to cause rock falls and slides both above and beneath the lake. Plots of maximum distance from earthquake epicenter to landslides for earthquakes of different magnitudes (Keefer, 1984, fig. 2) provide a guide to the likely effects at $C$ rater $L$ ake of earthquakes with epicenters at a distance of $60 \mathrm{~km}$, such as the September 1993, events. In this case, disrupted falls, slides, or avalanches could occur for $M \geq 5$.7. Theeffect of a large earthquake on the $C$ ascadia subduction zone can be evaluated from plots of magnitude versus maximum distance from the fault-rupture zone (Keefer, 1984, fig. 3), which we consider to be more relevant than the epicenter of a large, distant event. $\mathrm{H}$ ere, weassumea minimum distance of $100 \mathrm{~km}$ from the gently inclined fault-rupture zone and determine that disrupted falls or slidesmay occur for an earthquake of $M \geq 6.5$. Clearly, the maximum event (table 5 ) is more than adequate to induce disrupted falls and slides at $C$ rater Lake. A great earthquake on the C ascadia subduction zone would result in a longer duration of shaking, perhaps one to several minutes (Wong and Silva, 1996), than would a smaller local event and this undoubtedly would increase the probability of slides.

Another way to look at the potential for earthquake-induced rock falls and slides is in relation to the critical ground acceleration $\left(A_{C}=0.05 \mathrm{~g}\right.$; W ilson and Keefer, 1985) necessary to cause motion of incoherent materials. The peak ground acceleration for sites on "soil" (any unconsolidated material; "rock" sites experience smaller accelerations) is given as a function of earthquake magnitude and distance from sourcein a relation developed specifically for extensional tectonic regimes, such as the Crater Lake area, by Spudich and others (1997). The distance is that to the nearest point on the surface projection of the area that slipsin the earthquake. A peak horizontal acceleration of $0.05 \mathrm{~g}(+65 \% /-40 \%)$ would be expected to occur for a $M=5$ earthquake at a distance of $23 \mathrm{~km}, M=6$ at $42 \mathrm{~km}$, and $M=7$ at $73 \mathrm{~km}$. Earthquakes rupturing an area beneath Crater Lake, such as on the Annie Spring or Red Cone Spring faults projected downdip, could produce peak horizontal accelerations of $0.20 \mathrm{~g}$ for $M=5,0.34 \mathrm{~g}$ for $M=6$, and $0.57 \mathrm{~g}$ for $M=7$ (all g values $+65 \% /-40 \%$ ). Recognizing thesignificant 
uncertainties inherent in empirical relations such as the one used to calculate acceleration, these results are consistent with volcanic, local tectonic, or distant C ascadia subduction zone earthquakes all having the potential to trigger failure of the fractured and poorly consolidated rock of the caldera walls and talus slopes.

In a different type of analysis, Geomatrix Consultants (1995, plate 3a) indicatesa peak horizontal acceleration of $\sim 0.14 \mathrm{~g}$ for sites on rock near $C$ rater Lake and a return period of 500 years (mean annual frequency of exceedance of 0.002 ). This value takes earthquakes from all sources into consideration and includes estimates of the probability of earthquake occurrence. Increased return period (decreased mean annual frequency of exceedance) results in larger accelerations. Although not strictly comparable to our analysis, the Geomatrix study al so indicates that peak horizontal accelerations at $C$ rater Lake can significantly exceed $A_{C}$.

\section{Waves Generated by LandsLides INTO THE LAKE}

There are many examples of large waves caused by landslides. Those most relevant to the situation at $C$ rater Lakehaveoccurred in deep glacially-scoured bays and fjords where either a large mass of rock has fallen or slid into the water or where the submarine slopehas failed. A spectacular example of a seismically related rockfall and ensuing wave is the July 9, 1958, event at Lituya Bay, Alaska, described by M iller (1960). Lituya Bay is an ice-scoured, nearly landlocked tidal inlet adjacent to theFairweather Range and Fairweather fault in the Gulf of Alaska. It has a maximum depth of $220 \mathrm{~m}$. In the 1958 event, $30 \times 10^{6} \mathrm{~m}^{3}$ of rock plunged into a 1.2-km-wide inlet of the bay from an elevation of up to $-900 \mathrm{~m}$, causing water to surge over the opposite wall of theinlet to an elevation of $530 \mathrm{~m}$, and generating a wave that moved down the bay $11 \mathrm{~km}$ to its mouth at a probable velocity of 160 to $210 \mathrm{~km} / \mathrm{hr}$. M iller (1960) presents evidence for several lesser events at Lituya Bay caused by a variety of phenomena. Waves generated by landslides in N orwegian fjords and lakes are described by Jørstad (1968). Thecatastrophic waves induced by a rock slide at Tafjord $(8-9 \mathrm{~km}$ long $\times 1$-1.5 km wide $\times$ 200-220 m deep), N orway, April 7, 1934, traveled at between 20 and $100 \mathrm{~km} / \mathrm{hr}$, were 1-16 m in height 3-11 km from the slide, and reached a maximum of $62 \mathrm{~m}$ in height $200 \mathrm{~m}$ from the slide. In this event, a total of $2-3 \times 10^{6} \mathrm{~m}^{3}$ of rock plus scree entered the water from a maximum el evation of $730 \mathrm{~m}$. The Lituya Bay and Tafjord events are comparable in magnitude to a worst case scenario for Crater Lake. Rough cal culations of minimum volumes of bathymetric features that may belandslides at $C$ rater Lake are presented in table 6 . The Chaski Bay slide (fig. 3) has a minimum volume of $93 \times 10^{6} \mathrm{~m}^{3}$. The minimum volume of rock in the block forming the prominent bench at Chaski Bay is $15 \times 10^{6} \mathrm{~m}^{3}$. A far greater volume of fractured and altered rock of the caldera wall above this feature might be presumed to be capable of failure. We stress that in order for such a slide to pose a significant wave-generation hazard, the slide mass would have to move rapidly into the lake.

Theclosed basin of $C$ rater Lakecaldera (Proximal $\mathrm{H}$ azard Zone PA) is $\sim 8$ by $10 \mathrm{~km}$ at the rim and $\sim 7$ by $9 \mathrm{~km}$ at the shoreline. The maximum depth is $589 \mathrm{~m}$, a large part of the lake is at least $450 \mathrm{~m}$ deep, and the high points on the rim are $-600 \mathrm{~m}$ above the lake. Postcaldera volcanoes form hills on the caldera floor, including the edifice capped by Wizard Island. Three-dimensional numerical models have been developed that simulatethe effects of landslides entering bodies of water. Although the detailed propagation and character of waves induced by a landslide at $C$ rater Lake, initiated subaerially or subaqueously, cannot be predicted directly from published numerical models of other landslides in fjords (e.g., $\mathrm{H}$ arbitz and others, 1993) or in bodies of water adjacent to volcanoes (e.g., Kienle and others, 1987), the numerical models lend credence to our concernsabout C rater Lake. Initial waves likely would be followed by seiche effects caused by reflection of waves off of the caldera walls. Interference of waves could result in amplification.

The substantial depth of $C$ rater Lakewould cause a wave to travel at great speed. A common approach to determining the velocity of propagation is

$$
v=(g \times h)^{1 / 2}
$$

where $v=$ velocity, $g=$ gravitational acceleration, and $\mathrm{h}=$ water depth. For $\mathrm{h}=450 \mathrm{~m}, \mathrm{v}=66 \mathrm{~m} / \mathrm{s}$. For example, a wave initiated at Chaski Bay would reach the boat dock at Cleetwood Covein about two minutes. 
Theamplitude of the wave would diminish in the deep part of the lake but would increase on approach to the shore. Consequently, at the onset of shaking, perhaps as indicated by abundant, sudden rockfalls, it would be advisable for boats to head toward the center of the lake.

\section{WAVES GENERATED BY EARTHQUAKES}

Large waves or seiche effects caused by motion of the lakefloor during an earthquake would require that the natural period of free oscillation of the lake be similar to the period of seismic waves. Surface waves responsible for motion of the lake floor would have maximum periods of about 20 seconds. Thefirst mode of stationary oscillation of the lake is approximated by

$$
t=2 L \times(g \times h)^{-1 / 2}
$$

where $\mathrm{L}=$ length, which givest $=4$ minutes for $\mathrm{Crater}$ Lake, an order of magnitudelonger than the maximum period of seismic waves. It is thus unlikely that earthquakeshaking alonewould cause dangerous waves on the lake.

\section{PREPARING FOR AN EARTHQUAKE AFFECTING THE CRATER LAKE REGION}

A local earthquake of sufficient magnitude to seriously damage structures and disrupt transportation systems in the C rater Lake area probably does not occur more frequently than once every few thousand years. $M$ ore frequent may be large, distant earthquakes on the $C$ ascadia subduction zonefor which shaking might be less violent but of much longer duration. Residents may wish to maintain supplies of food, water, clothing, flashlights, and first-aid materials (see Protecting C rater Lake National Park and surrounding communities from volcano hazards), such as recommended for peopleliving in earthquake-prone areas elsewhere, and minimize the chances of large objects falling in their homes. Businesses and Crater Lake $\mathrm{N}$ ational Park should be aware of possible damage to structures, utilities, communication facilities, and transportation systems, in addition to the potential for rockfalls and dangerous waves on Crater Lake described above. Communities should develop plans for responding to the effects of an earthquake. A relevant local example of moderate earthquake damage is provided by the $M \approx 6$ "K lamath Falls" earthquakes of September 1993 (W iley and others, 1993; D ewey, 1993).

\section{ACKNOWLEDGMENTS}

$M$ any individuals contributed to the content of this report. Rick $\mathrm{H}$ oblitt advised us in delineation of proximal hazard zones. Ruth Ludwin kindly relocated earthquake epicenters. C arl M ortensen, D avid Schwartz, M ark Reid, and D avid Keefer provided information and advice on earthquake and landslide issues. Technical reviews by Willie Scott, Evelyn Roeloffs, and David Hill resulted in many improvements and clarifications of the manuscript. We are especially grateful to Steve Schilling for GIS preparation of plate 1 .

\section{REFERENCES}

Atwater, B.F., and others, 1995, Summary of coastal geologic evidence for past great earthquakes at the C ascadia subduction zone: EarthquakeSpectra, v. 11, p. 1-18.

Bacon, C.R., 1983, Eruptive history of M ount M azama and C rater Lake caldera, C ascade Range, U.S.A.: Journal of Volcanology and Geothermal Research, v. 18, p. $57-115$.

Bacon, C.R., and N athenson, M anuel, 1996, Geothermal resources in the Crater Lake area, O regon: U.S. Geological Survey 0 pen-File Report 96-663, 34 p.

Braunmiller, J., N abelek, J., Leitner, B., and Q amar, A., 1995, T he 1993 K lamath Falls, O regon, earthquake sequence: Soure mechanisms from regional data: Geophysical Research Letters, v. 22, p. 105-108.

Byrne, J.V., 1962, Bathymetry of Crater Lake, O regon: The O re Bin, v. 24, p. 161-164.

Collier, R.W., D ymond, Jack, and M CM anus, James, 1991, Studies of H ydrothermal Processes in C rater Lake, O R: College of O ceanography Report \#90-7, 0 regon State University, $317 \mathrm{p}$.

Crone, A.J., M achette, M.N., Bonilla, M.G., Leinkaemper, J.J., Pierce, K.L., Scott, W.E., and Bucknam, R.C., 1987, Surface faulting accompanying the Borah Peak earthquake and 
segmentation of the Lost River fault, central Idaho: Bullletin of the Seismological Society of America, v. 77, p. 739-770.

D ecker, Robert, and D ecker, Barbara, 1989, Volcanoes: W.H . Freeman and Co., N ew York, 285 p.

Dewey, J.W., 1993, Damages from the 20 Spetember earthquakes near Klamath Falls, O regon: Earthquakes \& Volcanoes, v. 24, n. 3, p. 121-128.

Ellsworth, W. L., 1990, Earthquake history, 1969-1989: in Wallace, R. E., ed., The San Andreas fault system, California: U.S. G eological Survey Professional Paper 1515, p. 152-187.

Endo, E.T., M alone, S.D ., N oson, L.L., and Weaver, C.S., 1981, Locations, magnitudes, and statistics of the $M$ arch 20- $M$ ay 18 earthquake sequence: in Lipman, P. W., and M ullineaux, D. L., The 1980 eruptions of Mount St. Helens, Washington: U.S. Geological Survey Professional Paper 1250, p. 93-107.

Francis, Peter, 1993, Volcanoes-A Planetary Perspective: O xford University Press, O xford, U.K., 443 pages.

Geomatrix Consultants, 1995, Seismic design mapping, State of $O$ regon: Report for $O$ regon $D$ epartment of Transportation, contract 11688.

Goter, S.K., 1994, Earthquakes in Washington and O regon, 1872-1993: U.S. G eological Survey, 0 penFile Report 94-226A, 1 sheet, scale 1:1,000,000.

Guffanti, M arianne, and Weaver, C.S., 1988, D istribution of late C enozoic volcanic vents in the $C$ ascade Range: Volcanic arc segmentation and regional tectonic considerations: Journal of Geophysical Research, v. 93, p. 6513-6529.

H arbitz, C.B., Pedersen, G., and G jevik, B., 1993, N umerical simulations of large water waves due to landslides: Journal of $\mathrm{H}$ ydraulic Engineering, v. 119, p. 1325-1342.

H awkins, F.F., Ake, Jon, and Vetter, U.R., 1992, Seismotectonic study for $\mathrm{H}$ oward Prai rie and $\mathrm{H}$ yatt dams, Rogue River Basin Project, O regon: U.S. Bureau of Reclamation, D enver, Colorado, Seismotectonic Report 92-4, 55 p.

H awkins, F.F., Foley, L.L., and LaForge, R.C., 1989, Seismotectonic study for Fish Lake and Fourmile Lake dams, Rogue River Basin Project, O regon: U.S. Bureau of Reclamation, Denver, Colorado, Seismotectonic Report 89-3, 26 p.

Jørstad, F., 1968, Waves generated by landslides in Norwegian fjords and lakes: Norwegian
G eothechnical Institute Publication 79, p. 13-32.

Keefer, D.K., 1984, Landslides caused by earthquakes: Geological Society of America Bulletin, v. 95, p. 406-421.

Keefer, D. K., and Schuster, R. L., 1993, Landslides caused by the Klamath Falls, O regon, earthquakes of September 20, 1993: Earthquakes and Volcanoes, v. 24, p. 140-146.

Kienle, Jürgen, Kowalik, Zygmunt, and M urthy, T.S., 1987, Tsunamis generated by eruptionsfrom M ount St. Augustine volcano, Alaska: Science, v. 236, p. 1442-1447.

Kling, G.W., Clark, M .A., C ompton, H .R., D evine, J.D ., Evans, W.C., H umphrey, A.M., Koenigsberg, E.J., Lockwood, J.P., Tuttle, M.L., and Wagner, G.N., 1987, T he 1986 LakeN yos gas disaster in Cameroon, west Africa: Science, v. 236, p. 169-175.

Kollmann, A., and Zollweg, J., 1984, 0 regon seismicity August 1980 to 0 ctober 1982: U.S. G eological Survey, O pen-File Report 84-832, 29 p.

Lorenz, V., 1970, Some aspects of theeruption mechanism of the Big H ole M aar, central O regon: Geological Society of America Bulletin, v. 81, p. 1823-1830.

M acLeod, N.S., and Sherrod, D .R., 1992, Reconnaissance geologic map of the west half of the C rescent $1^{\circ}$ by $2^{\circ}$ quadrangle, central 0 regon: U.S. Geological Survey M ap I-2215, scale 1:250,000.

M astin, L.G., 1995, Thermodynamics of gas and steamblast eruptions: Bulletin of Volcanology, v. 57, no. 2, p. 85-98.

M cM anus, James, 1992, On the chemical and physical limnology of Crater Lake, O regon: Ph.D. thesis, 0 regon State U niversity, $143 \mathrm{p}$.

M iller, D .J., 1960, Giant waves in Lituya Bay Alaska: U.S. Geological Survey Professional Paper 354-C, p. 51-86.

M oore, J.G ., 1985, Structure and eruptive mechanisms at Surtsey Volcano, Iceland: Geological Magazine, v. 6, p. 649-661.

M oore, J.G., N akamura, K., and Alcaraz, A., 1966, The 1965 eruption of Taal Volcano: Science, v. 151, p. 955-960.

Nairn, I.A., Wood, C.P., and H ewson, C.A.Y., 1979, Phreatic eruptions of Ruapehu: April 1975: N ew Zealand Journal of Geology and Geophysics, v. 22, n. 2, p. 155-173. 
Nelson, A.R., Shennan, Ian, and Long, A.J., 1996, Identifying coseismic subsidence in tidal-wetland stratigraphic sequences at the Cascadia subduction zone of western North America: Journal of G eophysical Research, v. 101, p. 6115-6135.

N elson, C.H ., Bacon, C.R., Robinson, S.W., Adam, D .P., Bradbury, J.P., Barber, J.H ., Jr., Schwartz, D eborah, and Vagenas, Ginger, 1994, The volcanic, sedimentologic, and paleolimnologic history of the $C$ rater Lakecaldera floor, $O$ regon: Evidencefor small caldera evolution: Geological Society of America Bulletin, v. 106, p. 684-704.

N elson, C.H ., C arlson, P.R., and Bacon, C.R., 1988, The M ount M azama climactic eruption ( $\sim 6900$ yr B.P.) and resulting convulsive sedimentation on the $C$ rater Lake caldera floor, continent, and ocean basin: in Clifton, H.E., ed., Sedimentologic consequences of convulsive geologic events: Geological Society of America Special Paper 229, p. 37-57.

N ewhall, C.G ., and D zurisin, D ., 1988, H istorical unrest at large calderas of the world, U.S. Geological Survey Bulletin 1855: Washington, D.C., U.S. Government Printing 0 ffice.

Pezzopane, S.K., and Weldon, R.J., II, 1993, Tectonic role of active faulting in central 0 regon: Tectonics, v. 12, P. 1140-1169.

Pezzopane, S.K., Sarna-Wojcicki, A.M , Weldon, R.J., II, and Langridge, R.L., 1996, Slip rate rand recurrence intervals for the Ana River fault, 0 regon: Geological Society of America Abstracts with Programs, v. 28, no. 5, p. 101.

Phillips, K.N ., and Van D enburgh, A.S., 1968, H ydrology of C rater, East, and D avis Lakes, O regon: U.S. G eological Survey Water-Supply Paper 1859-E, 60 p.

Q amar, Anthony, and M eagher, K.L., 1993, Precisely locating the Klamath Falls, O regon, earthquakes: Earthquakes \& Volcanoes, v. 24, n. 3, p. 129-139.

Ruapehu Surveillance Group, 1996, Volcanic eruption at a N ew Zealand ski resort prompts reevaluation of hazards: EOS, v. 77, n. 20, p.189-191.

Satake, Kenji, and Tanioka, Yuichiro, 1996, Tsunami heights along the Pacific N orthwest computed from the $M=9$ earthquake of January 1700: Geological Society of America Abstracts with Programs, v. 28, no. 5, p. 108.

Satake, Kenji, Shimazaki, Kunihiko, Tsuji, Yoshinobu, and U eda, Kazue, 1996, Time and size of a great earthquake in Cascadia inferred from Japanese tsunami records of January 1700: N ature, v. 379 , p. 246-249.

Scarpa, Roberto, and Tilling, R.I., eds., 1996, M onitoring and $\mathrm{M}$ itigation of Volcano $\mathrm{H}$ azards: Springer-Verlagn Berlin, $841 \mathrm{p}$.

Schwartz, D.P., and Coppersmith, K.J., 1986, Seismic hazards: N ew trends in analysis using geologic data: in Wallace, R. E., ed., Active Tectonics, National Academy Press, p. 215-230.

Scott, K.M ., 1988, O rigins, behavior, and sedimentology of laharsand lahar-runout flows in theToutle-C owlitz River System: U.S. Geological Survey Professional Paper 1447-A, $74 \mathrm{p}$.

Self, S., Kienle, J., and H uot, J.-P., 1980, U kinrek M aars, Alaska, II. Deposits and formation of the 1977 craters: Journal of Volcanology and Geothermal Research, v. 7, p. 39-65.

Sherrod, D.R., 1991, Geologic imap of a part of the Cascade Range between latitudes $43^{\circ}-44^{\circ}$, central 0 regon: U.S. Geological Survey M ap I-1891, scale 1:125,000.

Sherrod, D .R., 1993, H istoric and prehistoric earthquakes near K lamath Falls, O regon: Earthquakes \& Volcanoes, v. 24, n. 3, p. 106-120.

Sherrod, D.R., and Pickthorn, L.B.G., 1992, Geologic map of the west half of the Klamath Falls $1^{\circ}$ by $2^{\circ}$ quadrangle, south-central 0 regon: U.S. G eological Survey M ap I-2182, scale 1:250,000.

Smith, J.G., 1988, Geologic map of the Pelican Butte quadrangle, Klamath County, O regon: U.S. Geological Survey M ap I-1653, scale 1:62,500.

Smith, J.G., Page, N .J., Johnson, M.G., M oring, B.C., and Gray, Floyd, 1982, Preliminary geologic map of the $\mathrm{M}$ edford $1^{\circ} \times 2^{\circ}$ quadrangle, $O$ regon: U.S. Geological Survey 0 pen-File M ap 82-955, scale $1: 250,000$.

Spudich, P., Fletcher, J.B., H ellweg, M., Boatwright, J., Sullivan, C., Joyner, W.B., H anks, T.C., Boore, D .M ., M cGarr, A., Baker, L.M., and Lindh, A.G., 1997, Sea96-A new predictive relation for earthquake ground motions in extensional tectonic regimes: Seismological Research Letters, v. 68, p. 190-198.

University of Washington, 1993, Seismicity of Washington and western O regon, July 1 through September 30, 1993: U niversity of Washington, Geophysics Program, Quarterly Network Report 93-C, 29 p. 
Waters, A.C., and Fisher, R.V., 1971, Base surges and their deposits: Capelinhos and Taal volcanoes: Journal of G eophysical Research, v. 76, no. 23, p. 5596-5613.

Waythomas, C.F., Walder, J.S., M cGimsey, R.G., and N eal, C.A., 1996, A catastrophic flood caused by drainage of a caldera lake at Aniakchak Volcano, Alaska, and implications for volcanic-hazards assessment: G eological Society of America Bulletin, v. 108, P. $861-871$.

Weaver, C.S., 1989, Seismicity of the C ascade R angeand adjacent areas, in M uffler, L.J.P., Weaver, C.S., and Blackwell, D.D ., eds., G eological, Geophysical, and Tectonic Setting of the Cascade Range, U.S. Geological Survey, O pen-File Report 89-178, p. 74-93.

Wells, D.L., and Coppersmith, K.J., 1994, N ew empirical relationships among magnitude, rupture length, rupture width, rupture area, and surface displacement: Bulletin of Seismological Society of America, v. 84, p. 974-1002.

Westhusing, J.K., 1973, Reconnaissance surveys of nearevent seismic activity in the volcanoes of the $C$ ascade Range, O regon: Bulletin of Volcanology, v. 37, p. 258-286.
W iley, T.J., Sherrod, D .R., Keefer, D .K., Q amar, Anthony, Schuster, R.L., D ewey, J.W., M abey, M.A., Black, G.L., and Wells, R.E., 1993, Klamath Falls earthquakes, September 20, 1993-including the strongest quake ever measured in 0 regon: 0 regon Geology, v. 55, p. 127-134.

Williams, H owel, 1942, The geology of Crater Lake National Park: Carnegie Insitutiton of Washington Publication 540, 162 p.

Wilson, R.C., and Keefer, D.K., 1985, Predicting areal limits of earthquake-induced landsliding: in Ziony, J.I., ed., Evaluating earthquake hazards in the Los Angeles region: U.S. G eological Survey Professional Paper 1360, p. 317-345.

Wohletz, K.H., 1986, Explosive magma-water interactions: Thermodynamics, explosion mechanisms, and field studies: Bulletin of Volcanology, v. 48, p. 245-264.

Wong, I.G., and Bott, J.D.J., 1995, A look back at O regon's earthquake history, 1841-1994: O regon Geology, v. 57, p. 125-139.

Wong, I.G., and Silva, W.J., 1996, Implications of maximum magnitude for the Cascadia subduction zone to seismic hazards in the Pacific N orthwest: 
Geological Society of America Abstracts with Programs, v. 28, no. 5, p. 125-126.

Working Group on California Earthquake Probabilities, 1990, Probabilities of large earthquakes in the San Francisco Bay region, California: U.S. Geological Survey Circular 1053, $51 \mathrm{p}$.

\section{GLOSSARY}

andesite-magma containing about 57 to 63 percent $\mathrm{SiO}_{2}$; intermediatein eruptivecharacteristics between basaltic and silica-rich magma.

a sh - (volcanic) sand-sized or finer tephra; fragments are smaller than $2 \mathrm{~mm}$ (0.08 in) in diameter.

ba llistics, ballistic blocks- rock fragments explosively ejected from the vent on a ballistic arc.

basalt- low-silica magma (containing about 45 to 57 percent $\mathrm{SiO}_{2}$ ), which is the hottest and least viscous.

caldera-a large, basin-shaped volcanic depression, moreor lesscircular in form, with a diameter generally greater than 1 to $2 \mathrm{~km}$ (a mile or more).

cinder cone- a conical hill formed by accumulation of solidified bubble-rich droplets and clots of lava that fall around the vent during a single basaltic to andesitic eruption.

climactic eruption-(Crater Lake) the catastrophic, highly explosive eruption of $M$ ount $M$ azama about 7,700 years ago during which $C$ rater Lake caldera collapsed.

composite volcano- volcanic edifice formed by accumulation of lava and fragmental volcanic material from repeated eruptionsfrom a central vent or closely spaced vents; commonly forms a high, steep-sided, volcanic cone which may be referred to as a stratovolcano.

dacite- (Crater Lake) silica-rich magma containing 63 to 68 percent $\mathrm{SiO}_{2}$; see also silicic magma.

dome- volcanic domes are masses of solid rock that are formed when viscous lava is erupted slowly from a vent and piles up over it. The sides of most domes are very steep and typically are mantled with unstable rock debris formed during or shortly after dome emplacement.

hydromagmatic - said of an explosiveeruption caused by heating of water by magma or by physical mixing of magma and water.

lahar-a watery flow of volcanic rocks and mud that surges downstream like rapidly flowing concrete; also called mudflow or debris flow.

K-Ar dating - the potassium (K) - argon (Ar) method of radiometric data of rocks and minerals. The radioactiveisotope of potassium $\left({ }^{40} \mathrm{~K}\right)$ decays to stable argon $\left({ }^{40} \mathrm{Ar}\right)$ at a known rate. M easurement of the amounts of $\mathrm{K}$ and radiogenic ${ }^{40} \mathrm{Ar}$ present in a rock or mineral specimen allows calculation of theelapsed time since the material was sealed to Ar loss. For unaltered volcanic rocks, the timesincecrystallization of the magma is determined.

magma-molten rock, which may also contain suspended crystals and(or) gas bubbles; forms lava or tephra upon eruption at the Earth's surface.

magma cha mber- a reservoir of magma beneath the Earth's surface.

monogenetic volcano-a volcano built up by a single eruption or series of like eruptions closely spaced in time.

paleomagnetic studies-investigations of the orientation and(or) intensity of the Earth's magnetic field in the past, as recorded in geologic materials. The magnetic poles wander about the Earth's axis of rotation and the paleomagnetic pole position at the time of cooling of a volcanic rock is "frozen in" by magnetic minerals. An empirical calibration of this "secular variation" over time allows eruption ages to be constrained and isolated outcrops to be correlatred with one another.

plinian eruption- an explosive eruption in which a steady, turbulent stream of fragmented magma and magmatic gas is released at high velocity from a vent producing a towering eruption column that rises buoyantly into the atmosphere.

postcaldera eruption-volcanic eruption occurring after caldera formation.

preclimactic eruption-(Crater Lake) volcanic eruption of rhyodaciteoccurring in theapproximately 20,000 years beforethe climactic eruption of M ount M azama.

pyrocla stic flow - dense, hot mixture of volcanic rock fragments (pyroclasts) and gases that, driven by gravity, flows down a volcano's flank at high speed.

pyroclastic surge- turbulent, relatively low-density mixture of gas and rock fragments that, driven by gravity, flows abovetheground surface at high speed. 
regional volcanism - ( $C$ ascades) volcanic activity represented by widespread, generally basaltic to andesitic monogenetic volcanoes, including cinder cones and shield volcanoes, forming a background for the larger centers of the $C$ ascades (composite volcanoes).

rhyodacite- (C rater Lake) silica-rich magma containing 68 to 72 percent $\mathrm{SiO}_{2}$; see also silicic magma.

shield volcano-a broad, gently sloping mound composed of numerous overlapping and superimposed lava flows; resembles the shape of a warrior's shield or an inverted shallow bowl; typically basaltic in C ascades but may be andesite.

silicic magma- magma that contains more than 63 percent $\mathrm{SiO}_{2}$ and is generally the most viscous and gas-rich; includes dacite, rhyodacite, and rhyolite (the last not present at Crater Lake).

tectonic earthquake- an earthquake caused by sudden slip on a fault rather than by subsurface movement of magma or a volcanic eruption.

tephra-collectively, all fragmental rock material, including magma, ejected during a volcanic explosion or eruption.

vent- the opening at the Earth's surface through which volcanic materials are ejected.

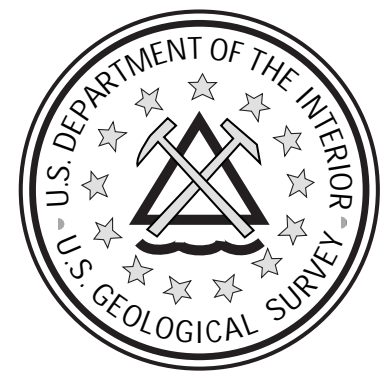

